\title{
Global recognition that ecosystems are key to human resilience in a warming world
}

\author{
Nathalie Seddon ${ }^{1 *}$, Elizabeth Daniels ${ }^{3}$, Rowan Davis ${ }^{4}$, Rian Harris ${ }^{5}$, Xiaoting Hou-Jones ${ }^{2}$, \\ Saleemul Huq ${ }^{6}$, Valerie Kapos ${ }^{7}$, Georgina M. Mace ${ }^{8}$, Ali Raza Rizvi ${ }^{9}$, Hannah Reid ${ }^{2}$, Dilys \\ Roe $^{2}$ and Sylvia Wicander ${ }^{7}$
}

Ecosystems are not merely vulnerable to climate change but, if sustainably restored and protected, are a major source of human resilience. Not only is the science evidencebase for this perspective growing rapidly, but ecosystems are featuring with increasing prominence in global climate change policy. Of 167 climate pledges submitted by the signatories of the Paris Climate Change Agreement (representing 194 nations), 103 include commitments to the restoration, management or protection of natural habitats in their adaptation strategies (of which $\mathbf{7 0}$ are aimed at protecting human communities from climate change hazards, i.e. ecosystem-based adaptation). A further 27 describe similar actions in their mitigation plans. In total, $65 \%$ of Paris Agreement signatories commit to restoring and/or protecting natural ecosystems. However, commitments rarely translate into robust science-based targets. As the world takes stock of the Agreement in 2018 and climate pledges are revised, we urge the science community to work closely with policy makers to identify meaningful adaptation targets that benefit both people and the ecosystems on which they depend.

Keywords: Biodiversity, climate change adaptation, ecosystems, Paris Agreement, policy

$\mathrm{F}$ ailure to adapt to the effects of climate change has been identified as the single greatest risk to health, wealth and wellbeing around the world 1 . Identifying and implementing robust adaptation approaches that are cost-effective and build resilience across a range of potential future climates is therefore critical. To date, the dominant approach has been a mix of direct engineered (or 'grey') interventions such as sea walls, levees or irrigation infrastructure and indirect (or 'soft') interventions such as early warning systems and awareness raising ${ }^{2}$. However, there is growing recognition that ecosystem-based (or 'green') approaches - i.e. restoration and protection of natural habitats - when applied strategically and equitably can not only safeguard biodiversity and ecosystem services but also help people adapt to the effects of climate change ${ }^{3}$.

\section{What is Ecosystem-based Adaptation?}

Ecosystem-based Adaptation (EbA) is formally defined by the Convention on Biological Diversity (CBD) as the use of

${ }^{1}$ Nature-based Solutions Initiative, Department of Zoology, University of Oxford, Oxford OX1 3PS, UK; ${ }^{2}$ International Institute for Environment and Development, Grays Inn Road, London WC1X 8NH, UK; 3Stockholm Environment Institute Oxford, 29 Grove Street, Oxford OX2 7JT, UK; ${ }^{4}$ School of Geography and the Environment, University of Oxford, South Parks Rd, Oxford OX1 3QY, UK; ${ }^{5}$ Faculty of Health Sciences, University of Bristol, Senate House, Tyndall Avenue, Bristol, BS8 1TH, UK; ${ }^{6}$ International Centre for Climate Change and Development, House-27, Road 1, Block-A, Bashundhara R/A, Dhaka 1229, Bangladesh; ${ }^{7}$ UN Environment World Conservation Monitoring Centre, 2019 Huntingdon Road, Cambridge CB3 ODL, UK; ${ }^{8}$ Centre for Biodiversity and Environment Research, University College London, London, UK; IInternational Union for the Conservation of Nature, 1630 Connecticut Ave NW, Washington, DC 20009, USA 
ecosystems and biodiversity to help human communities adapt to the effects of climate change ${ }^{4}$ (Box 1). Examples include the restoration of coastal ecosystems to protect communities from storm surges and erosion ${ }^{5-7}$, agroforestry to stabilise crop yields in drier climates 8,9 , and forest restoration in headwaters and riparian zones to secure and regulate water supplies and protect communities from flooding, soil erosion, and landslides ${ }^{10-12}$. While the evidence base is variable and still developing, it is clear that, in many cases, EbA can provide low cost, low risk and low maintenance solutions for managing many climate change related hazards 13,14 . Most significantly, and in contrast to engineered solutions to the same hazards, EbA and socalled 'hybrid' (i.e. grey and green together) approaches can provide multiple co-benefits in addition to adaptation, such as access to food and water, carbon storage, and diversified livelihoods ${ }^{15-19}$ (Box 1).

EbA complements conventional approaches to natural resource and biodiversity management and broadly speaking is a type of "nature-based solution" 20 to the effects of climate change. However, it is distinctive from traditional conservation because it focuses on adaptation needs and co-benefits (rather than prioritising conservation outcomes) and places these in the context of an overall adaptation strategy, through participatory, community-centric processes21,22.

The fact that EbA can be low risk, low cost and provide a wide range of cobenefits 13,16 , suggests it should feature prominently in national climate change plans and policy processes. To get a global sense of the extent to which this is the case, we reviewed the prominence of $\mathrm{EbA}$ in the climate pledges of all signatories to the Paris Agreement of the United Nations

Framework Convention on Climate Change (UNFCCC).

\section{Adaptation in the Paris Agreement}

The Paris Agreement of UNFCCC has huge political momentum, having been signed by 197 nations and ratified by 181 (as of September 2018). To date, most analyses and debates have focused on the Agreement's mitigation targets and whether they are sufficiently ambitious to limit global warming to $1.5^{\circ} \mathrm{C}$ above preindustrial levels ${ }^{23}$. However, the Agreement also addresses adaptation and emphasises "enhancing adaptive capacity, strengthening resilience and reducing vulnerability to climate change, with a view to contributing to sustainable development and ensuring an adequate adaptation response in the context of the temperature goal" (Article 7.1). It calls on its parties to pursue actions "on the basis of equity, and in the context of sustainable development and efforts to eradicate poverty" (Article 4.1). Effective EbA has the potential to support these calls for increased adaptive capacity and resilience, as well as sequestering carbon, and contributing to sustainable development ${ }^{24}$ (Box 1). As such, the proper implementation of EbA can help countries to meet both mitigation and adaptation obligations under the Paris Agreement (and a number of other international agreements) ${ }^{25}$.

The Agreement requires all Parties to set out current and future mitigation and adaptation actions in the form of a 
Nationally Determined Contribution (NDC) document submitted to UNFCCC. Ratifying nations must submit new NDCs every five years, in which they are required to report on progress towards achieving the purpose of the Agreement. To determine the extent of commitment to EbA explicitly or otherwise we conducted an in-depth textual analysis of all 167 NDCs currently available, broadly reflecting the climate mitigation and adaptation plans of 194 nations.

Analysis. Of these 167 NDCs, 166 were submitted to UNFCCC ${ }^{26}$ by signatories of the Paris Agreement (including one submitted on behalf of all 28 European Union member states) and one was produced by Taiwan (which is not a signatory). Within each NDC adaptation component, we noted whether a country articulated a high-level commitment to EbA (i.e. their "adaptation vision") and whether such a commitment was substantiated with tangible actions. An EbA action was defined as the protection and/or restoration of natural ecosystems explicitly aimed at (i) dealing with the hazardous effects of climate change (including delivering broader socio-economic co-benefits), and/or (ii) involving participatory, community centric approaches. If actions lacked both these characteristics, we classified them as "traditional conservation". In the NDCs, ecosystem-orientated activities, whether $\mathrm{EbA}$ or traditional conservation, were described to take place in one or more of five broad, non-mutually exclusive types of ecosystem: (i) coastal and marine habitats (i.e. corals, mangroves, seagrass meadows and saltmarshes), (ii) terrestrial forests or woodlands (excluding mangroves), (iii) river catchment habitats (including wetlands), (iv) grasslands and rangelands, and (v) montane habitats. Agroforestry (including conservation agriculture and permaculture) was also classified as EbA. We noted whether EbA actions are currently underway or included as part of future plans, and whether targets are quantitative (and hence measurable), longterm and/or costed. We also analysed whether any EbA visions or actions were described within the mitigation component of the NDCs. For the full final dataset and details of methods used, see Supplementary Material available online and via the Nature-based Solutions Policy Platform (www.nbspolicyplatform.org).

We acknowledge that countries may be doing far more on adaptation than described in their NDCs and that many have other policy processes addressing climate change, such as National Adaptation Plans (NAPs) i.e. formal, country specific medium- and long-term plans on which greater emphasis may be placed. Consequently, for some countries we may underestimate the true extent of ecosystem-based approaches in adaptation planning. However, rather than providing detailed insight into the plans of all countries, the overarching objective of our analysis was to present broad overview of global commitment to EbA through the lens of the Paris Agreement of the UNFCCC, a legally-binding policy process that has considerable political momentum and an inbuilt mechanism for reporting on progress towards goals (i.e. the "global stocktake" every five years). Within this broad objective, our specific aims were to (i) gauge high-level interest in EbA using a 


standardised
approach
across all
countries, (ii)
highlight best
practice in
the treatment
of EbA in the
NDCs in
order guide
their revision
in 2018-2020;
and (iii)
provide the
basis for
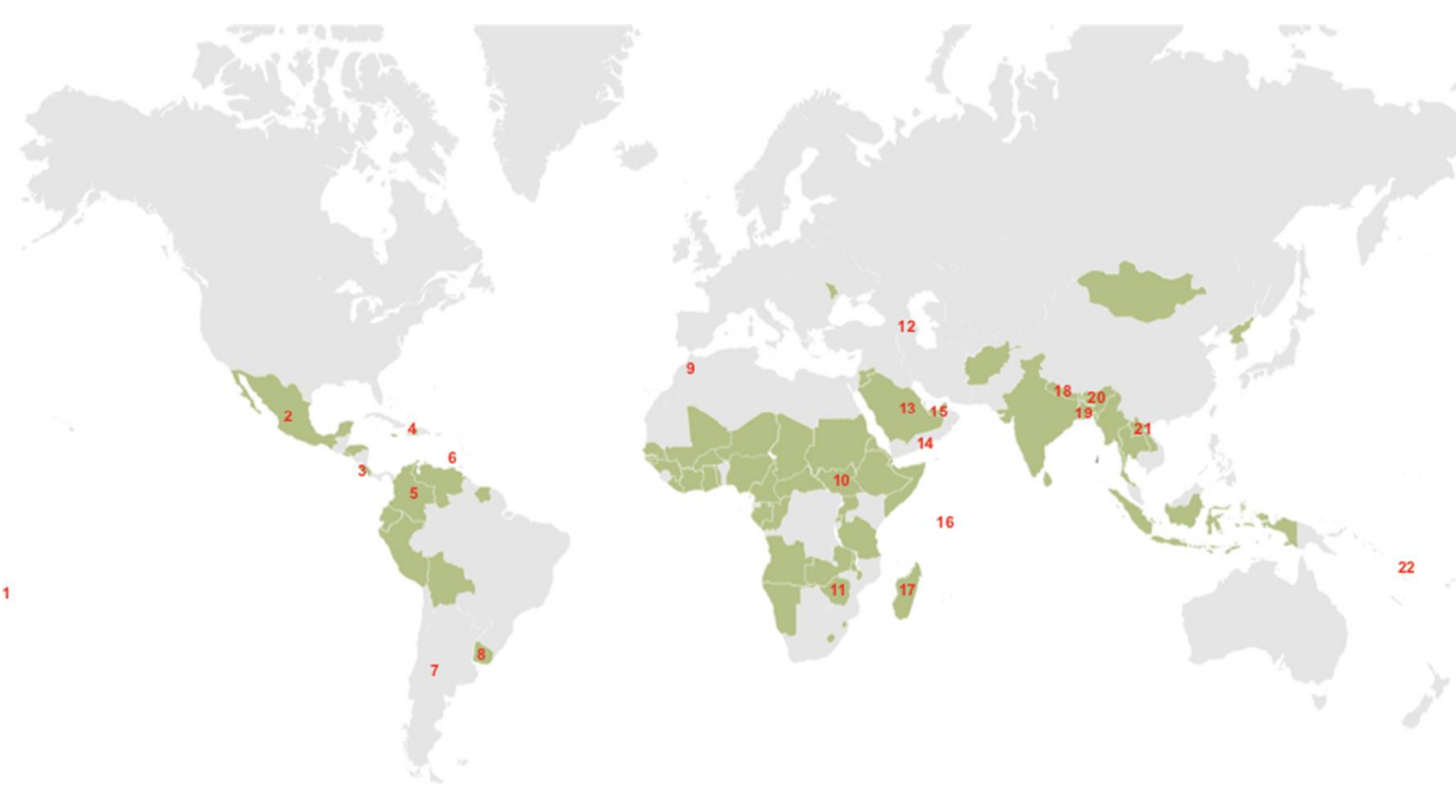

Fig. 1. Commitment to ecosystem-based adaptation (EbA) actions across the globe as indicated by the inclusion of such actions described in the adaptation components of the NDCs $(n=70)$. Red numbers denote the 22 nations that explicitly include $\mathrm{EbA}$ in their vision for climate change adaptation: 1, Niue; 2, Mexico; 3, Costa Rica; 4, Dominican Republic; 5, Colombia; 6, Grenada; 7, Argentina; 8, Uruguay; 9, Morocco; 10, South Sudan; 11, Zimbabwe; 12, Armenia; 13, Saudi Arabia; 14; Yemen; 15, United Arab Emirates; 16, Seychelles; 17, Madagascar; 18, Nepal; 19, Bangladesh; 20, Myanmar; 21, Vietnam; 22, Vanuatu. Several nations have a level commitment to EbA, but lack current or planned EbA actions (e.g. 7, 9,12).

guidelines on how we might scale-up and mainstream EbA into national policy.

\section{Prominence of EbA in the NDCs}

Twenty-one countries explicitly recognise the importance of, or state a high-level commitment to, EbA in their NDCs (Figure 1). For example, Costa Rica has "committed to develop its adaptation practice from an ecosystem based adaptation focus", while Armenia "embraces the ecosystem approach for adapting to climate change". Mexico and South Sudan are the only countries to adopt the official CBD definition of EbA (Box 1), with Mexico listing $\mathrm{EbA}$ as one of three broad areas of adaptation, ranking it alongside "adaptation for the social sector" and "adaptation of strategic infrastructure and productive systems".

A further 29 countries acknowledge, albeit with a varying degree of detail, the importance of the interdependencies between natural ecosystems and human adaptation without explicitly using the term EbA. One example of "implicit" visions for EbA comes from Ethiopia, which aims to "enhance the adaptive capacity of ecosystems, communities and infrastructure through an ecosystem rehabilitation approach"; another example comes from Cambodia, which commits to "promoting and improving the adaptive capacity of communities, especially through community based adaptation actions, and restoring the natural ecology system to 
respond to climate change" (see Table S1 for all EbA vision statements).

We found mismatches between adaptation visions and actions in many of the NDCs. Specifically, of 51 NDCs with

an adaptation vision that includes $\mathrm{EbA}$, explicitly or otherwise, only 35 then go on to describe tangible EbA actions (Table S2). The remainder either describe traditional conservation activities with no obvious characteristics of EbA (7 NDCs) or entirely lacked reference to ecosystems in their adaptation plans (9 NDCs). A further 35 countries, though lacking an EbA vision, nonetheless describe EbA actions. For example, Sudan commits to introducing "agroforestry in areas vulnerable to climate change to enhance agricultural production as well as empower vulnerable communities through their involvement in community forests activities / products" (see Table S2 for all EbA actions described in the NDCs).

In total, 70 countries commit to $\mathrm{EbA}$ actions within the adaptation component of their NDC (Figure 1). An additional 33 propose conservation activities such as the establishment of protected areas or habitat restoration but without any explicit links to enhancing social or ecological resilience to climate change or the involvement of local communities. For example, Bahrain refers to "a mangrove transplantation project for the cultivation of plants and planting mangrove seedlings in order to rehabilitate degraded coastal areas" and Tunisia commits to "conservation of the ecological functions of low-lying coastal areas". We classified these actions as traditional conservation activities based on review of the limited information available in NDCs but we recognise that some of these may have EbA characteristics if a more detailed analysis of actions beyond the NDCs were undertaken. Of the 33 nations committing to traditional conservation actions, three also refer to community-based adaptation (CbA), whether as part of a high-level vision or commitment, or as tangible actions. In such cases, greater coherence among conservation and adaptation planning represents a potential quick win for these countries to scale up EbA.

\section{Quick wins: capitalising on EbA and conservation commitments in a mitigation context}

Twenty-seven countries, though lacking reference to $\mathrm{EbA}$ or traditional conservation in the adaptation component of their NDCs, refer to such actions or broad commitments in the mitigation components. Of these, seven refer to actions or commitments that although are not technically EbA, on the basis that they are not designed to address adaptation needs, are "EbA-like" in that they meet other criteria for EbA. For example, Vietnam lacks specific EbA actions in the adaptation component of its NDC but in its mitigation component seeks to "manage and develop sustainable forest, enhance carbon sequestration and environmental services; conservation of biodiversity associated with livelihood development and income generation for communities and forest-dependent people". These ecosystem-based commitments, although not specifically targeting adaptation needs, could still benefit communities by increasing their resilience 
to a changing climate, thus achieving the same outcomes as EbA. By examining these planned actions and adjusting them for greatest effectiveness in addressing climate vulnerability, countries can achieve adaptation as well as mitigation.

In total, we found that 103 countries have committed to $\mathrm{EbA}$ and/or traditional conservation in their adaptation plans, while 27 do so in their mitigation plans. In other words, a total of $65 \%$ of all signatories to the Paris Agreement (and 78\% of associated climate pledges) have committed to managing, restoring and/or protecting natural ecosystems to address the causes and consequences of climate change.

\section{Regional variation in commitment to EbA actions}

Commitment to EbA actions in the NDCs is more apparent in low and lower middleincome countries. While EbA actions are included in the adaptation plans of $77 \%$ of low-income countries and $55 \%$ of lower middle-income countries, this is true of only $29 \%$ of upper middle-income countries and only $12 \%$ of high-income countries (Figure 1; Table 1). We note that no Annex 1 countries (i.e. industrialised OECD members and economies in transition) commit to EbA actions in their NDC. In contrast, all countries committing to $\mathrm{EbA}$ actions are classified by UNFCCC as developing. This includes 34 of the 48 least developed countries (LDCs), which are given special consideration by UNFCCC "on account of their limited capacity to respond to climate change and adapt to its adverse effects" (see Supplementary Material).
Our analysis suggests a greater commitment to EbA in African countries than elsewhere, with 35 out of 53 NDCs submitted by African countries (66\%) implementing or planning for EbA. This contrasts with Latin America and the Asia and Pacific regions where only $47 \%(15 / 32)$ and $34 \%(16 / 47)$ of countries respectively commit to EbA actions (Table 1). Also of note is the finding that only 10 of the 18 countries classified as having high or medium-high vulnerability to climate change (as determined by the Global Climate Risk Index ${ }^{27}$ ) commit to EbA actions. Of the remaining eight, four are Central American or Caribbean nations (Bahamas, Dominica, Dominican Republic and Guatemala) and four are in South or South-east Asia (Cambodia, Pakistan, Philippines and Vietnam). EbA actions, as part of a suite of adaptation interventions including hybrid and engineered solutions, could play an important role in increasing the resilience and adaptive capacity of vulnerable communities in these regions.

\section{Types and strength of EbA activities}

To highlight any potential biases in implementation and identify contexts in which EbA action may need to be enhanced, we reviewed the types and strengths of current or planned EbA activities across the globe. The most commonly implemented or planned $\mathrm{EbA}$ action is agroforestry (highlighted in 39 of 70 , i.e. $56 \%$ of NDCs with EbA actions); followed by the protection and/or restoration of terrestrial forests or woodlands (46\%), coastal and marine habitats $(24 \%)$, and river catchments (including wetland) (20\%; (Figure 2, Table 
2). Far rarer, overall, are plans to restore and protect montane habitats $(4 \%)$ or grasslands and rangelands (11\%); we note that almost all examples of grassland or rangeland $\mathrm{EbA}$ actions come from Africa, despite the extensive presence of these habitats on other continents.

In Africa, there is a focus is on agroforestry and, to a lesser extent, the protection and/or restoration of terrestrial forests or woodlands. Out of the 35 African countries implementing or planning for EbA action, 27 include agroforestry and 16 include forest protection and/or restoration. In the Asia and Pacific region, the most common $\mathrm{EbA}$ action is the restoration and/or protection of terrestrial forests or woodlands, often through community management (11 out of 16 countries stating $\mathrm{EbA}$ actions). However, we note that this contributes to and has crossover with other EbA actions, particularly in particular the protection of ecosystems within river catchments. For example, Thailand has committed to increase "national forest cover to $40 \%$ through local community participation, including in particular headwater and mangrove forests to enhance adaptive capacities of related ecosystem[s]".

Of the 70 NDCs with EbA actions, only 25 could be classified as "robust" i.e. with evidence of the ecosystem-based action being both community-centric and prioritizing adaptation and other socioeconomic benefits to people, with over half of these involving terrestrial forest conservation and agroforestry (Table S2, Figure 2). Of particular note was that despite widespread anecdotal association of $\mathrm{EbA}$ with coastal areas (for example the use of mangroves as coastal defences) $)^{5-7}$, we found that ecosystem-based activities followed the more traditional model of conservation: out of 46 NDCs describing ecosystem-based activities in the coastal zone, only 17 included actions with EbA characteristics. Instead, of all habitats referred to in the NDCs, terrestrial forest conservation was where EbA actions were most numerous and well-defined (Table 2).

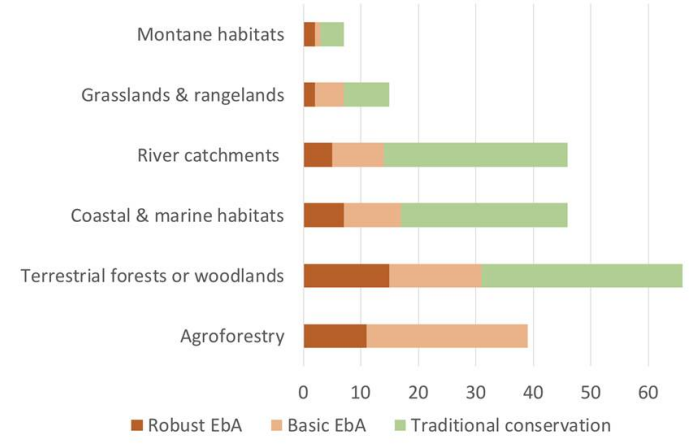

Fig. 2. Numbers of NDCs committing to different types and strengths of EbA actions in five broad ecosystems types. Traditional conservation is defined as actions taken to restore and/or protect natural habitats that prioritize positive outcomes for nature without explicit regard for climate change impacts on human communities. EbA actions, by contrast, are defined as activities that restore and protect natural ecosystems (i) with the explicit aim of protecting humans from the impacts of climate change and providing other socio-economic benefits, and/or (ii) involving participatory, community-centric approaches. $A$ basic EbA action as one that involves (i) or (ii); a robust EbA action has both attributes.

\section{$\mathrm{EbA}$ as a future priority, pending funding}

Only $23 \%$ countries with EbA actions describe current initiatives or projects. For example, Peru refers to the United Nations Environment Programme's "Mountain EbA Project" and the Seychelles declares that it "is currently implementing three ecosystem-based adaptation projects... [which] focus on management of coastal ecosystems, protection of mangroves, and 
sustainable watershed management collectively". The majority (77\%) present $\mathrm{EbA}$ as a future priority, and one that is conditional on external financing. In other words, though the finding that 70 countries include tangible EbA actions in their NDCs is encouraging, the concern is whether these plans will get translated into action on the ground. A major issue is that only a handful of countries describe distinct technical and financial needs for specific EbA activities. One example comes from Afghanistan which, in stating an action for the "regeneration of at least $40 \%$ of existing degraded forests and rangeland areas", refers to technology needs of "forestry and rangeland management tools and methods", capacity building needs of "practitioners group built in university, government and local delivery levels" and finance needs of "USD 2.5 billion". Far more countries outline broader technology, capacity development and finance needs required across all adaptation actions, not only EbA. Attention is needed to make sure that resources provided in response to these general needs generate suitable increases in capacity than can be applied to EbA.

\section{Need for clear and measurable targets}

Many countries articulate a theoretical commitment to adaptation actions, including $\mathrm{EbA}$, but this rarely translates into clear targets. Even where measurable targets are set, it is unclear whether they will be sufficient to meet the adaptation needs of the communities and ecosystems involved. Of the 70 countries that commit to one or more $\mathrm{EbA}$ actions in the adaptation component of their NDCs, only 18 provide either time-bound or quantitative targets and, of those, only 12 are broadly measurable and so could be tracked in theory (SOM Table S2 for key actions).

Measurable targets generally concern the protection or restoration of specific areas of habitat within given timeframes. For example, Bolivia states that it will "increase forest areas with integrated and sustainable community management approaches with 16.9 million hectares in 2030, in reference to 3.1 million hectares by 2010" (Table S2). Some targets also include the types and numbers of communities involved: Burkina Faso states that "200 rural communes [will] develop and implement [...] assisted natural regeneration projects with the participation of at least five village communities each" involving an area of 800,000 hectares. Other targets centre on agroforestry. For example, Ghana is aiming for "modified community-based conservation agriculture [to be] adopted in 43 administrative districts, and Rwanda "intends to mainstream agro ecology technologies in its current agriculture intensification programme and other natural resource-based livelihood programmes. $100 \%$ of the households involved in agriculture production will be implementing agro forestry sustainable food production by 2030". The remaining NDCs that provide either time-bound or quantitative targets (6) outline targets that are more difficult to measure. For example, Guinea-Bissau aims to "develop a national reforestation and sustainable management of forest and agro forestry ecosystems programme by $2025^{\prime \prime}$.

\section{Integrating science and local knowledge}




\section{into adaptation planning}

Compared to mitigation where there is substantial effort to measure and monitor progress towards country targets 23,28 , much less headway has been made on measuring and tracking adaptation ${ }^{29}$. Without specific, measurable targets and suitable indicators, progress towards broad adaptation goals cannot be assessed. Even where such targets are set, how do we know whether they are sufficient to meet the adaptation needs of the communities and ecosystems they involve? There is an opportunity for countries to design specific EbA projects as part of their national adaptation strategies, explicitly addressing nationally relevant climate change risks while actively contributing to other development priorities.

EbA activities should be designed in light of the best available science and local knowledge but it is unclear whether the $\mathrm{EbA}$ targets set out in the NDCs derive from an understanding of the effects of different management practices on ecosystems or take into account future climate change scenarios. A number of NDCs recognise that action plans addressing climate threats should be science-based and make highlevel commitments to this. For example, Antigua and Barbuda states that its NDC is "fair, ambitious and science-based" and the Bahamas commits to "enhancing the science base to better understand the relationship between climate change and health outcomes". More interestingly, 100 of the 166 NDCs submissions include current or planned research or monitoring measures, such as the development of climate information (e.g. monitoring of climate variables, development of future climate change scenarios or climate modelling for projections) and research into more effective processes or measures (e.g. climate risk and vulnerability assessment processes and adaptation technologies). Such actions will be critical in strengthening the scientific basis for future adaptation planning, including the design and implementation of $\mathrm{EbA}$ actions. We note that research actions are proposed for ecosystems where $\mathrm{EbA}$ actions are currently limited in scale, such as montane areas. For example, India has "launched [the] National Mission on Himalayan Studies [...] with the objective of building a body of scientific and traditional knowledge along with demonstrating replicable solutions to [...] natural resource management, capacity building, long-term ecological monitoring". The integration of local needs and knowledge into the development of ecosystem and climate science will be a critical basis for future EbA and broader adaptation planning. Considerable effort is underway to track the mitigation targets in the Paris Agreement ${ }^{23}$. The same attention must now be given to setting and tracking targets for adaptation, and this is going to take the full engagement of the science community.

\section{Conclusions and next steps: embedding EbA in the 2030 development agenda}

Our analysis reveals that the protection and/or restoration of natural ecosystems is central to the adaptation ambition of many countries across the globe. However, some of the most biologically diverse and climatevulnerable countries do not refer to EbA in their NDCs, including many LDCs with 
limited capacity to adapt to the adverse effects of climate change. Of those countries implementing or planning to implement EbA actions, very few include clear and measurable science-based targets towards which progress can be assessed. Given growing evidence that $\mathrm{EbA}$ is a low cost, low risk adaptation option that provides a wide range of co-benefits and offers protection against multiple hazards ${ }^{17}$, efforts to engage all countries in EbA should be stepped up to inform the continuing development of NAPs and the next iteration of NDCs, with much greater engagement from the ecosystem and conservation science community.

We found that for many nations there is a mismatch between high level visions and on-the-ground actions. In a handful of such cases, detailed plans are instead provided in other national policy documents (e.g. NAPs), suggesting the need for greater coherence among different national policy processes. For the majority, however, the mismatch indicates a lack of understanding of how best to integrate $\mathrm{EbA}$ within adaptation planning processes, and underscores the need for better support to policymakers and planners in translating theoretical EbA approaches into locally relevant actions. More broadly, the high variance in what different nations term as 'actions' (some being broader and visionlike and others closely defined with tangible outputs) make them difficult to compare effectively. The lack of consistency, and thus comparability, between the adaptation components needs to be addressed as NDCs are revised in 2018-2020 (see Box 2 for policy recommendations).

As more countries pledge to protect and restore their natural ecosystems (e.g. The Bonn Challenge, New York Declaration on Forests, Aichi Biodiversity Targets, CBD post 2020 Biodiversity Framework) and prioritise measures that can deliver both mitigation and adaptation benefits, EbA could become a powerful and attractive option that can help countries deliver on international commitments, meet the Sustainable Development Goals with limited finance and ultimately achieve sustainable and equitable development in a warming world. The key challenges are to clarify and properly disseminate understanding of what makes EbA effective, to build capacity among practitioners across the globe to develop robust adaptation plans fine-tuned to local socio-ecological contexts, access suitable levels of adaptation finance and/or technical support and ultimately implement effective EbA for the benefit of people and the planet.

\section{References}

1. WEF. The Global Risks Report 2016. (2016).

2. Jones, H. P., Hole, D. G. \& Zavaleta, E. S. Harnessing nature to help people adapt to climate change. Nat. Clim. Chang. 2, 504509 (2012).

3. Stein, B. A. et al. Preparing for and managing change: climate adaptation for biodiversity and ecosystems. Front. Ecol. Environ. 11, 502-510 (2013).

4. Secretariat of the Convention on Biological Diversity. Connecting Biodiversity and Climate Change Mitigation and Adaptation: Report of the Second Ad Hoc Technical Expert Group on Biodiversity and Climate Change. (2009)

5. Das, S. \& Vincent, J. R. Mangroves protected villages and reduced death toll during Indian super cyclone. Proc. Natl. Acad. Sci. U. S. A. 106, 7357-60 (2009). 
6. Temmerman, S. et al. Ecosystem-based coastal defence in the face of global change. Nature 504, 79-83 (2013).

7. Arkema, K. K. et al. Coastal habitats shield people and property from sea-level rise and storms. Nat. Clim. Chang. 3, 913-918 (2013).

8. Mbow, C., Smith, P., Skole, D., Duguma, L. \& Bustamante, M. Achieving mitigation and adaptation to climate change through sustainable agroforestry practices in Africa. Curr. Opin. Environ. Sustain. 6, 8-14 (2014).

9. Lasco, R. D., Delfino, R. J. P., Catacutan, D. C., Simelton, E. S. \& Wilson, D. M. Climate risk adaptation by smallholder farmers: the roles of trees and agroforestry. Curr. Opin. Environ. Sustain. 6, 83-88 (2014).

10. Ebert, S., Hulea, O. \& Strobel, D. Floodplain restoration along the lower Danube: $A$ climate change adaptation case study. Clim. Dev. 1, 212-219 (2009).

11. Mueller, J. M., Swaffar, W., Nielsen, E. A., Springer, A. E. \& Lopez, S. M. Estimating the value of watershed services following forest restoration. Water Resour. Res. 49, 1773-1781 (2013).

12. Huang, L., Shao, Q. \& Liu, J. Forest restoration to achieve both ecological and economic progress, Poyang Lake basin, China. Ecol. Eng. 44, 53-60 (2012).

13. Doswald, N. et al. Effectiveness of ecosystem-based approaches for adaptation: review of the evidence-base. Clim. Dev. 6, 185-201 (2014).

14. Narayan, S. et al. The Value of Coastal Wetlands for Flood Damage Reduction in the Northeastern USA. Sci. Rep. 7, 9463 (2017).

15. Daigneault, A., Brown, P. \& Gawith, D. Dredging versus hedging: Comparing hard infrastructure to ecosystem-based adaptation to flooding. Ecol. Econ. 122, 2535 (2016).

16. Munang, R., Andrews, J., Alverson, K. \& Mebratu, D. Harnessing Ecosystem-based Adaptation To Address the Social Dimensions of Climate Change. Environ. Sci. Policy Sustain. Dev. 56, 18-24 (2014).

17. The Royal Society. Resilience to extreme weather. (2014).

18. van der Nat, A., Vellinga, P., Leemans, R. \& van Slobbe, E. Ranking coastal flood protection designs from engineered to nature-based. Ecol. Eng. 87, 80-90 (2016).

19. van Slobbe, E. et al. Building with Nature: in search of resilient storm surge protection strategies. Nat. Hazards 65, 947-966 (2013).

20. Nesshöver, C. et al. The science, policy and practice of nature-based solutions: An interdisciplinary perspective. Sci. Total Environ. 579, 1215-1227 (2017).

21. Vignola, R. et al. Ecosystem-based adaptation for smallholder farmers: Definitions, opportunities and constraints. Agric. Ecosyst. Environ. 211, 126-132 (2015).

22. Girot, P. et al. Integrating community and ecosystem-based approaches in climate change adaptation responses. Ecosyst. Livelihoods Adapt. Netw. (ELAN). Ecosyst. Livelihoods Adapt. Netw. (ELAN), USA (2012).

23. Peters, G. P. et al. Key indicators to track current progress and future ambition of the Paris Agreement. Nat. Clim. Chang. 7, 118122 (2017).

24. Janetos, A. C., Malone, E., Mastrangelo, E., Hardee, K. \& de Bremond, A. Linking climate change and development goals: framing, integrating, and measuring. Clim. Dev. 4, 141-156 (2012).

25. Seddon, N. et al. Ecosystem-based approaches to climate change adaptation: a new framework and research priorities for evaluating effectiveness. Research overview and overarching questions. Report. London, International Institute for Environment and Development. (2016).

26. NDCs as communicated by Parties submitted to UNFCCC, available at: http://www4.unfccc.int/submissions/indc/Su bmission Pages/submissions.aspx. (Accessed: 5th January 2018)

27. Kreft, S., Eckstein, D. \& Melchior, I. Global Climate Risk Index 2017. (2016).

28. du Pont, Y. R. et al. Equitable mitigation to achieve the Paris Agreement goals. Nat. Clim. Chang. 7, 38-43 (2017).

29. United Nations Environment Programme. The Adaptation Gap Report 2017 - Towards Global Assessment. (2017).

30. Spalding, M. D. et al. Coastal ecosystems: A critical element of risk reduction. Cons. Letts. 7, 293-301 (2014). 


\section{Acknowledgements}

This study was conducted as part of the International Climate Initiative (IKI) project 'Ecosystem-Based Adaptation:

Strengthening the Evidence and Informing Policy', coordinated by the International Institute for Environment and Development, the International Union for the Conservation of Nature and the World Conservation Monitoring Centre of the United Nations Environment Programme. The German Federal Ministry for the Environment, Nature Conservation, Building and Nuclear Safety (BMUB) supports the IKI on the basis of a decision adopted by the German Bundestag. Additional support to Nathalie Seddon was provided by a Natural Environmental Research Council Knowledge Exchange Fellowship.

\section{Author contributions}

N Seddon, E Daniels, R Davis and R Harris collated the data and conducted the analyses. N Seddon and E Daniels wrote the manuscript, with significant input from $R$ Davis; all co-authors commented. 
5 Table 1 Numbers of NDCs featuring EbA and/or traditional conservation visions for adaptation (explicitly or implicitly) and/or tangible actions organized with respect to income and geographical region

\begin{tabular}{|c|c|c|c|c|c|c|c|c|c|c|c|}
\hline \multirow[b]{2}{*}{ Vision } & \multirow[b]{2}{*}{ Actions } & \multirow[b]{2}{*}{ All } & \multicolumn{4}{|c|}{ Income group ${ }^{1}$} & \multicolumn{5}{|c|}{ Geographical region² } \\
\hline & & & Lower & $\begin{array}{l}\text { Lower } \\
\text { Middle }\end{array}$ & $\begin{array}{l}\text { Upper } \\
\text { Middle }\end{array}$ & Upper & Africa & $\begin{array}{l}\text { Asia and } \\
\text { Pacific }\end{array}$ & Europe & $\begin{array}{c}\text { Latin America } \\
\text { and } \\
\text { Caribbean }\end{array}$ & $\begin{array}{l}\text { West } \\
\text { Asia }\end{array}$ \\
\hline \multirow[t]{4}{*}{ Explicit EbA } & No Actions & 4 & 0 & 2 & 1 & 0 & 0 & 1 & 1 & 1 & 1 \\
\hline & $\begin{array}{l}\text { Conservation } \\
\text { Actions }\end{array}$ & 3 & 0 & 2 & 1 & 0 & 1 & 1 & 0 & 1 & 0 \\
\hline & EbA Actions & 15 & 4 & 3 & 4 & 4 & 4 & 4 & 0 & 5 & 2 \\
\hline & Total & 22 & 4 & 7 & 6 & 4 & 5 & 6 & 1 & 7 & 3 \\
\hline \multirow[t]{4}{*}{ Implicit EbA } & No Actions & 5 & 0 & 2 & 2 & 1 & 0 & 1 & 0 & 4 & 0 \\
\hline & $\begin{array}{l}\text { Conservation } \\
\text { Actions }\end{array}$ & 4 & 0 & 2 & 1 & 1 & 1 & 2 & 0 & 0 & 1 \\
\hline & EbA Actions & 20 & 7 & 6 & 7 & 0 & 9 & 5 & 0 & 6 & 0 \\
\hline & Total & 29 & 7 & 10 & 10 & 2 & 10 & 8 & 0 & 10 & 1 \\
\hline \multirow{4}{*}{$\begin{array}{l}\text { Ecosystem- } \\
\text { orientated }\end{array}$} & No Actions & 9 & 0 & 3 & 4 & 2 & 2 & 3 & 0 & 2 & 2 \\
\hline & $\begin{array}{l}\text { Conservation } \\
\text { Actions }\end{array}$ & 17 & 4 & 4 & 5 & 3 & 7 & 4 & 0 & 4 & 2 \\
\hline & EbA Actions & 20 & 10 & 8 & 2 & 0 & 11 & 5 & 1 & 2 & 1 \\
\hline & Total & 46 & 14 & 15 & 11 & 5 & 20 & 12 & 1 & 8 & 5 \\
\hline \multirow[t]{4}{*}{ No Vision } & No Actions & 46 & 0 & 7 & 18 & 21 & 3 & 17 & 19 & 4 & 1 \\
\hline & $\begin{array}{l}\text { Conservation } \\
\text { Actions }\end{array}$ & 9 & 3 & 1 & 4 & 1 & 4 & 2 & 0 & 1 & 2 \\
\hline & EbA Actions & 15 & 3 & 10 & 2 & 0 & 11 & 2 & 0 & 2 & 0 \\
\hline & Total & 70 & 6 & 17 & 24 & 22 & 18 & 21 & 19 & 7 & 3 \\
\hline \multicolumn{2}{|c|}{ Total (submitted NDCs) } & 167 & 31 & 49 & 51 & 33 & 53 & 47 & 21 & 32 & 12 \\
\hline \multicolumn{2}{|c|}{ EbA Actions (total) } & 70 & 24 & 27 & 15 & 4 & 35 & 16 & 1 & 15 & 3 \\
\hline
\end{tabular}

${ }^{1}$ World Bank income classifications available at: https:// datahelpdesk.worldbank.org/knowledgebase/articles/906519-world-bank-country-andlending-groups; ${ }^{2} \mathrm{NDCs}$ submitted by USA and Canada lack an adaptation component and so the North American region is not included. 
10 Table 2 Numbers of NDCs featuring EbA and/or traditional conservation ("cons") actions for adaptation (explicitly or implicitly) organized with respect to World Bank income group, geographical region and the ecosystem type in which the action is occurring or planned

\begin{tabular}{|c|c|c|c|c|c|c|c|c|c|c|c|}
\hline \multirow[b]{2}{*}{ Ecosystem } & \multirow[b]{2}{*}{$\begin{array}{l}\text { Action } \\
\text { Type }\end{array}$} & \multirow[b]{2}{*}{ All } & \multicolumn{5}{|c|}{ Income group } & \multicolumn{4}{|c|}{ Geographical region } \\
\hline & & & Lower & $\begin{array}{l}\text { Lower } \\
\text { Middle }\end{array}$ & $\begin{array}{l}\text { Upper } \\
\text { Middle }\end{array}$ & Upper & Africa & $\begin{array}{l}\text { Asia + } \\
\text { Pacific }\end{array}$ & Europe & $\begin{array}{l}\text { Latin } \\
\text { America + } \\
\text { Caribbean }\end{array}$ & West Asia \\
\hline \multirow{2}{*}{ River catchments } & Cons & 46 & 16 & 22 & 5 & 4 & 22 & 16 & 1 & 7 & 1 \\
\hline & EbA & 14 & 5 & 5 & 3 & 1 & 5 & 6 & 0 & 3 & 0 \\
\hline \multirow{2}{*}{$\begin{array}{l}\text { Terrestrial forests } \\
\text { or woodlands }\end{array}$} & Cons & 67 & 24 & 27 & 12 & 4 & 35 & 19 & 1 & 10 & 2 \\
\hline & $\mathrm{EbA}$ & 32 & 14 & 13 & 5 & 0 & 16 & 11 & 1 & 4 & 0 \\
\hline \multirow{2}{*}{$\begin{array}{c}\text { Coastal and marine } \\
\text { habitats }\end{array}$} & Cons & 46 & 12 & 12 & 12 & 9 & 18 & 14 & 0 & 10 & 4 \\
\hline & $\mathrm{EbA}$ & 17 & 4 & 4 & 5 & 4 & 7 & 4 & 0 & 4 & 2 \\
\hline \multirow{2}{*}{ Montane habitats } & Cons & 7 & 2 & 3 & 2 & 0 & 3 & 2 & 0 & 2 & 0 \\
\hline & $\mathrm{EbA}$ & 3 & 1 & 1 & 1 & 0 & 1 & 1 & 0 & 1 & 0 \\
\hline \multirow{2}{*}{$\begin{array}{l}\text { Grassland and } \\
\text { rangeland }\end{array}$} & Cons & 16 & 8 & 8 & 0 & 0 & 14 & 1 & 0 & 1 & 0 \\
\hline & $\mathrm{EbA}$ & 8 & 5 & 3 & 0 & 0 & 7 & 1 & 0 & 0 & 0 \\
\hline Agroforestry & $\mathrm{EbA}$ & 39 & 17 & 18 & 4 & 0 & 27 & 6 & 0 & 5 & 1 \\
\hline
\end{tabular}


Box 1 What is EbA and is it effective? The widely adopted Convention on Biological Diversity (CBD) definition of EbA is: "the use of biodiversity and ecosystem services ... to help people adapt to the adverse effects of climate change" which "may include sustainable management, conservation and restoration of ecosystems, as part of an overall adaptation strategy that takes into account the multiple social, economic and cultural co-benefits for local communities." 4 It is often defined as being an alternative to "grey" engineering although really there is a spectrum of interventions which include components of both (i.e. hybrid or "grey-green" approaches).

Evidence about the effectiveness of different adaptation approaches is dispersed across different literatures and weakened by multiple framings and a lack of standardized metrics. Although much work is underway to test EbA and hybrid approaches ${ }^{30}$, data collection and monitoring is rarely planned when projects are designed, and there are currently no standards to ensure that monitoring will be effective and allow comparison with other options. Much currently available evidence is anecdotal, not peer-reviewed and does not record failures ${ }^{13}$. To enable broad comparisons, a recent semi-quantitative review compared $\mathrm{EbA}$, hybrid and engineered approaches to reducing risks to people from extreme weather events (coastal and riverine flooding, heatwaves, drought) using a combination of literature and expert scores and opinion ${ }^{17}$. This assessment compared the effectiveness of each option (encompassing both magnitude of the event against which the intervention can be effective and spatial scale over which it is effective) versus its affordability (combining both initial and long-term (to 2050) costs of intervention) (Fig. S1). It also scored intervention with respect to the number of co-benefits it brought (Fig. S2).
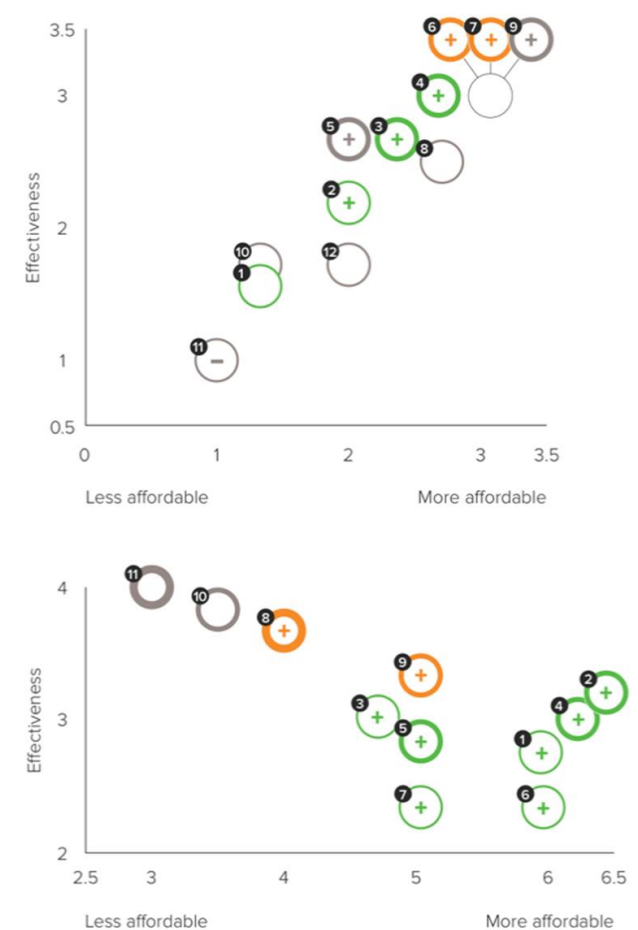

Fig. S1 Cost-effectiveness of EbA (green), engineered (grey) and hybrid (orange) adaptation approaches to $\mathbf{a}$, drought and $\mathbf{b}$, coastal flooding. Strength of available evidence increases with thickness of circle lines; signs within circles denote whether overall there are positive, negative or no co-benefits (e.g. ecosystem services) of the approach; numbers within circles refer to the type of adaptation approach. a, Drought adaptation: (1) removal of 'thirsty' invasive plant species, (2) reforestation, (3) forest conservation, (4) agroforestry, (5) breeding drought resilience crops and livestock, (6) sustainable agroecosystem management practices, (7) soil and water conservation, (8) reservoirs, points and other water storage, (9) wells, (10) irrigation, (11) inter-basin water transfer and (12) waste water re-cycling. $\mathbf{b}$, Coastal flooding adaptation: (1) maintenance of natural reefs (coral/oyster), (2) mangrove maintenance, (3) mangrove planting and re-establishment, (4) maintenance of saltmarshes, wetlands and intertidal ecosystems, (5) creation of saltmarshes, wetlands and inter-tidal ecosystems, (6) maintenance of other coastal vegetation, (7) coastal revegetation/ afforestation(above inter-tidal zone), (8) beach and dune nourishment, (9) artificial reefs (and/or substrates for reef replenishment), (10) dykes, levees, (11) coastal barrages. Reproduced with permission from @ The Royal Society 2014. 
The assessment found that engineered approaches have immediate, measurable impacts and are particularly effective in reducing the impacts of specific hazards over the short-term. However, they are expensive and deliver few if any co-benefits. In contrast, EbA is affordable, provides a wide range of ecosystem services and offers protection from multiple hazards, which is important as hazards seldom occur in isolation but can take place simultaneously or in a cascade. For example, coastal forests can protect against coastal and inland flooding, strong winds, and high temperatures, whilst providing a range of ecosystem services and supporting more diverse livelihoods. In contrast to engineered approaches, EbA also involves and benefits local people, can be more adaptive to new conditions, and is less likely to create a false sense of security. Set against these merits, EbA tends to be less effective than engineered structures over the short-term (i.e. effects are hard to quantify and can take time to manifest themselves), can take up larger areas of land, and involve the use of ecosystems that are themselves vulnerable to climate change. Meanwhile, hybrid approaches are intermediate in terms of effectiveness and affordability, but often have positive additional consequences. For example, two of the most affordable and effective hybrid options against drought are using 'sustainable agro-ecosystem management practices' and 'soil and water conservation'. These are bundles of separate, mutually reinforcing, small interventions, involving some EbA elements, changes to agricultural practices and low-tech engineering, which can be tailored to local contexts. Overall, hybrid approaches have the most positive consequences, and are marginally higher than ecosystem-based approaches for all the factors considered in the assessment (Fig. S2).

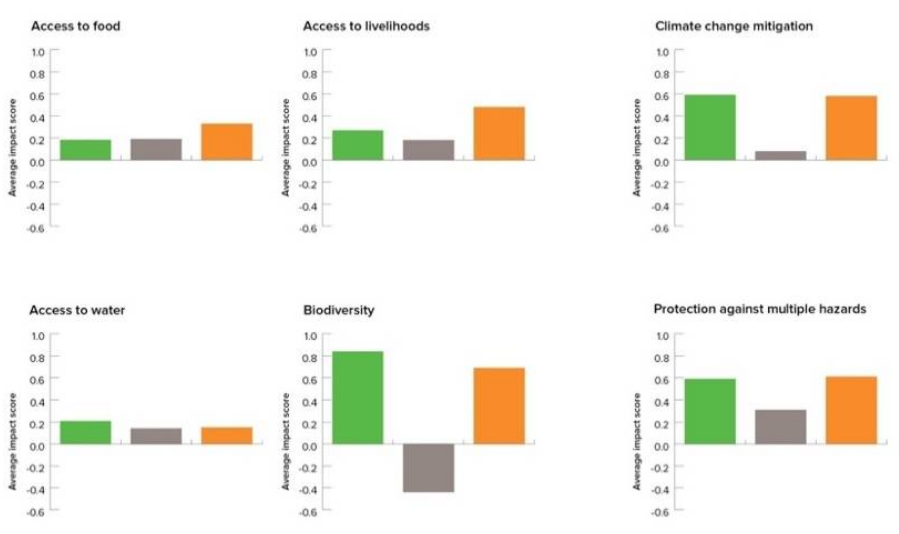

Fig S2. Additional consequences of different categories of adaptation options Average impact score of ecosystem-based (green), engineered (grey) and hybrid (orange) options, across all types of extreme event considered, on each additional consequence assessed. CRoyal Society 2014

The assessment concluded that despite the shortcomings of EbA and in the face of uncertainty around both risks and effectiveness, EbA is a 'low risk' or 'no regret' option that provides more positive consequences than those that are engineering-based. On the basis of the assessment, policy recommendations were to: (1) consider defensive options beyond traditional engineering approaches (e.g. EbA and hybrid approaches that offer additional benefits to people) including the conservation of natural ecosystems which are difficult or impossible to restore; and 
(2) monitor and evaluate the effectiveness of interventions, in particular of EbA, and apply the results to improve future decision-making. 


\section{BOX 2: Actions needed to scale-up and mainstream EbA into national policy}

National governments are strongly encouraged to: 1) establish measurable and meaningful EbA targets in national plans, drawn on best available scientific evidence, local knowledge and best practice; 2 ) report on progress towards targets these in the NDCs, NAPs and other climate policy processes outside the UNFCCC; 3) support the scaling-up EbA actions in all natural ecosystems; 4) rank EbA alongside other key elements of sustainable development (e.g. agriculture, finance), and 5) incorporate ecosystem services in development planning processes.

Researchers from the natural and social sciences and economists should work together to build a strong evidence base for socio-economic and ecological effectiveness of EbA compared to other adaptation options and facilitate the development of targets and costed plans. To promote consistency and comparability of adaptation planning across the globe, researchers also needs to harmonise methods for evaluating effectiveness of EbA and work with agencies revising the NDCs to ensure information is available in a useful format.

Practitioners should consider increasing implementation of EbA across the globe and share best practice and learning on what makes EbA effective (or otherwise); they should ensure that this knowledge informs the development of robust targets and shapes not only the redrafting of the NDCs in 2020 but climate change planning and policy in general.

Agencies revising NDCs in 2020 are advised to increase transparency and comparability of adaptation plans, and better align them with mitigation plans. With regards to EbA, rigour in the NDCs would be improved by 1) addressing mismatches between visions and actions for $\mathrm{EbA} ; 2)$ using consistent terminology based on scientific consensus; 3 ) aligning commitments to EbA in the mitigation component with those in the adaptation component; 4 ) aligning commitments to community based conservation actions and commitments to EbA; and 5) harmonizing the content of the NDCs with NAPs and other climate and development policy processes.

\section{Leading platforms funding or supporting mitigation and resilience strategies} - such as UN-REDD Carbon Fund, Green Climate Fund, and associated bilateral initiatives - are recommended to adopt a holistic approach by highlighting and promoting EbA and its co-benefits for sustainable development. 


\section{SUPPLEMENTARY INFORMATION}

\section{Supplementary Methods}

\section{Sample of Nationally Determined Contributions (NDCs)}

The Paris Agreement has 197 Parties: 195 signatories, plus Syria and Nicaragua which joined the agreement after the deadline for formal signing had passed. Of these Parties, 194 have submitted Nationally Determined Contributions (NDCs); Libya, Syria and Nicaragua are yet to do so ${ }^{1}$. One NDC was submitted for the European Union on behalf of all 28 member states. Therefore, there are 166 NDCs available for analysis from Parties, plus one from Taiwan. Although Taiwan is not a party to the UNFCCC and the United States of America has signalled its withdrawal from the Paris Agreement, both nations' NDCs were reviewed and are included in all final figures throughout this paper. NDC submissions were accessed using the official UNFCCC portal ${ }^{1}$, with the exception of Taiwan's NDC2.

This dataset is based on an in-depth review of NDCs, and does not include other national adaptation plans (i.e. National Adaptation Plans or National Adaptation Plans of Action) unless these were attached to the NDC or direct links to websites or other documents relating to current adaption projects were provided. Strategies or policies (including NAPs and NAPAs) that were listed in NDCs but without links or specific explanation for what relevant information could be located within such documents were not reviewed in our analysis. We focused our review and analysis on NDC documents as a high-level indicator of interest in EbA and to follow a standardised approach across all countries. While other planning documents such as NAPs and national climate change and biodiversity strategies may provide greater detail on adaptation plans and how commitments are implemented, not all countries have yet written NAPs or detailed national level strategies in the context of adaptation. As such, reviewing these in place of or in addition to NDCs could bias analyses. However, we acknowledge that countries may be doing far more than described in their NDCs, and that consequently for some nations we may underestimate the true extent of adaptation planning.

NDC adaptation component: visions, actions and targets

Overview and dataset: We conducted a systematic quantitative content analysis ${ }^{3}$ of the text of the adaptation and mitigation components of the NDCs ( $n=141$ NDCs for adaptation and 167 NDCs for mitigation). We classified statements in the adaptation component of the NDCs with respect to whether they described adaptation "visions", "actions" and 
"targets". We then coded vision and action statements with respect to whether they described EbA or traditional conservation activities in one of five non-mutually exclusive broad habitat types (defined below) and we coded whether actions were "robust" or "basic", current, planned and dependent on external sources of finances. We coded targets with respect to whether they were quantitative and measurable (details below). Two different observers (authors NS and ED) independently performed the classification and coding process on all 167 NDC documents, while two others (RD and RH) repeated the procedure for approximately half of the documents each. In this way, each NDC was carefully reviewed three times by three different independent observers. The lead observer conducted an audit process of the other two observers' reviews to achieve a degree of repeatability; discrepancies were discussed and resolved. The final dataset comprising coded adaptation plans as described in the current versions of the NDCs is publically available on the Nature-based Solutions Policy Platform (www.nbspolicyplatform.org).

Vision or commitment: A high-level pledge or statement of recognition of the importance of particular adaptation approach such as EbA, either implicitly or explicitly. An explicit EbA vision use the terms "ecosystem-based adaptation", "ecosystem-based approaches to adaptation", "forest-based adaptation", "ecosystem based climate change adaptation", "socio-ecosystem based adaptation" or "ecosystems approach", but does not include "adaptation of ecosystems" as this was assumed to be a commitment to the conservation of ecosystems for their intrinsic value. An implicit EbA vision acknowledges importance of protecting or restoring natural ecosystems for the benefit of human adaptation or resilience without explicitly referring to the foregoing terms. Commitments to the conservation or protection of ecosystems for their intrinsic value were not included; there needed to be an evident link or connection between the protection of ecosystems and the adaptation or resilience benefits for people.

Action: A tangible, locally relevant action or intervention in a particular habitat or the development/implementation of a specific and relevant policy or process. We considered an action to be broadly "ecosystem-based" or "green" if it referred to the protection, restoration or sustainable management of natural ecosystems. We subdivided such actions into two categories, traditional conservation and $\mathrm{EbA}$, based on the presence or absence of evidence of EbA characteristics arising from the CBD definition (Box 1)4:

a) the explicit provision of socio-economic benefits;

b) the use of participatory, community based approaches to natural habitat protection and/or restoration, or agroforestry; and 
c) actions developed to address adaptation needs.

Characteristic (c) was assumed where an action was stated within the adaptation component of an NDC. Where there was evidence of both characteristics (a) and (b) related to an action it was classified as 'robust $\mathrm{EbA}^{\prime}$ and where evidence was present of only one characteristic it was classified as 'basic $\mathrm{EbA}^{\prime}$, broadly followed the strong-weak EbA assessment framework for EBA quality developed by the Friends of EbA consortium 5 . Actions that evidenced only characteristic (b) could be community based conservation actions (i.e. proposed to meet biodiversity conservation goals as opposed to community resilience goals) but for our purposes were still considered as EbA.

Agroforestry activities were classified as basic EbA on the assumption that they are always community centric. Where clear evidence existed of the motivation to provide socio-economic benefits from agroforestry activities e.g. improved food security or incomes, the action was marked as strong EbA. Where specific EbA projects were noted, a similar approach was followed. They were assumed to be basic EbA unless additional detail was provided on socio-economic benefits in which case they were classified as strong. Green actions that did not exhibit either of characteristics (a) or (b) were classified as traditional conservation. We define traditional conservation actions that prioritize positive outcomes for nature without explicit regard for climate change impacts; they have no obvious involvement of local communities nor are aimed at the provision of socioeconomic benefits.

We assessed whether actions are currently underway or included as part of future plans. Where actions were stated within future plans, we classified these (where possible) as being either conditional or unconditional on external financing and support from the international community. In a number of cases there was lack of clarity over the temporal nature of actions: in these cases, we assumed actions to be planned (when no evident timescale provided), conditional (when the action appeared to rely on both unconditional and conditional financing) and both conditional and unconditional (when no information was provided regarding financing). Assumptions were made when terms such as "strengthen" or "improve" were used in relation to an action that the stated action was already underway. By classifying actions as current, we recognise that these actions in many cases are also proposed to continue in future. It should be recognised that there is a high degree of variation between what different nations term as 'actions' - some being broader and vision-like and others closely defined with tangible outputs.

\section{Ecosystem types:}


In the NDCs, ecosystem-orientated activities, whether EbA or traditional conservation, were described to take place in one or more of five broad, non-mutually exclusive types of ecosystem:

(i) Coastal and marine habitats: including mangroves, seagrass meadows, coastal wetlands and saltmarshes but not including references to Integrated Coastal Zone Management (ICZM) or equivalent (unless specific reference was made to ecosystem-oriented or based activities).

(ii) Terrestrial forests or woodlands: includes references to assisted natural regeneration; excludes mangroves.

(iii) River catchments: includes wetlands and rivers; lake management or preservation and any fluvial measures, watershed and wetland management; measures to protect or preserve large water bodies (including internal seas). Where natural resource management is discussed in relation to watersheds or wetlands, this measure is assumed to be an ecosystem-based. Does not include riverbank protection projects (this may be through engineered or soft approaches), water conservation or management outside watersheds

(iv) Grasslands and rangelands (including savanna); and

(v) Montane habitats

Agroforestry (a sixth category of EbA) included conservation agriculture and permaculture activities, "agricultural and forestry systems", "silvopasture" and the planting of trees in agricultural areas to reduce soil erosion.

NDCs do not use common, standardised terminology for ecosystem types. As such, some actions were classified across multiple classes, for example the protection of coastal wetlands was classified as both a coastal and marine action and a catchment action. Common overlaps were noted between terrestrial forest actions and other categories, predominantly catchments, montane and agroforestry. Forest conservation and protection was noted as action in catchment and montane landscapes as well as alongside agroforestry activities. Where a specific habitat or ecosystem type was not specified for a particular action, that action was considered as a 'general' nature based action and was not assigned one of the six broad categories listed above.

Climate smart agriculture (CSA) activities were not classified as EbA as they can include both hard and soft approaches such as the introduction of irrigation systems, drought resistant crop varieties, integrated agriculture and aquaculture systems or the use of seasonal rainfall forecasts in agricultural planning7. As such we consider CSA activities to be a hybrid adaptation measure unless further detail is stated. 
Research and monitoring: An assessment of the presence of research and monitoring actions/measures in the adaptation component of NDCs was conducted. Research and monitoring activities included within cross-cutting components of the NDC but which evidently referred to supporting adaptation rather than mitigation plans were also considered. For this review, research or monitoring measures were considered as those that seek to build and strengthen the climate science on which adaptation actions are based, namely:

(i) research and actions to develop and strengthen climate information e.g. establishment of weather stations, monitoring of climate variables and current weather patterns, development of future climate change scenarios or climate modelling for projections;

(ii) monitor observed and model projected impacts e.g. monitoring of rivers and aquifers, flood monitoring, crop monitoring and research, development of impact models

(iii) research into more effective processes or measures e.g. climate risk and vulnerability assessment processes and new adaptation technologies.

Monitoring, reporting and verification of mitigation or adaptation actions/measures and research undertaken for NDC methodologies were not considered within our definition of research and monitoring actions.

Targets: For actions that were categorised as EbA (either basic or robust), we assessed stated targets. We refer to a target as either a time-bound or quantitative target linked to an action. Broad goals or commitments (often linked to visions) are not classified as targets. For stated targets linked to actions we assessed whether such targets are measurable and long-term/strategic. We considered a target 'measurable' if the activity appeared sufficiently precise or focused to be monitored. Targets outlined for 2020 and beyond, and those not related to specific funded projects, were considered as strategic/long-term targets. Note that the assessment of targets was based on the limited information available in NDCs and an element of subjectivity exists in denoting targets as measurable or more difficult to measure.

\section{NDC mitigation component}

Within each NDC mitigation component, we identified whether EbA-like approaches or traditional conservation were proposed. We did not differentiate between high-level visions/commitments and actions, instead accepting either as evidence from the mitigation component. Visions/commitments to EbA were accepted as well as actions that 
exhibited one or more EbA characteristics or attributes (see earlier: the explicit provision of socio-economic benefits, the use of participatory, community based approaches to conservation, restoration, or agroforestry and addressing adaptation needs). We refer to these actions as 'EbA-like' as they have not been designed to explicitly address adaptation needs and so cannot be considered as true EbA. They do however exhibit other characteristics of EbA and we therefore deemed them to resemble EbA approaches. Within mitigation components we considered ecosystem-based actions to be habitat protection or restoration activities such as afforestation, reforestation, wetland and peatland management. REDD (reduce emissions from deforestation and forest degradation in developing countries) readiness activities ${ }^{6}$ and other policy and institutional strengthening measures were not considered in our review. Agroforestry activities were classified as EbA-like on the assumption that these activities are always community based in nature.

\section{Other datasets}

We organised NDC data with respect to income, UNFCCC grouping, region, and vulnerability to climate change. Official World Bank classifications and data were used for income and region groupings ${ }^{8}$. UNFCCC groupings including the list of countries classified as Annex 1, non-Annex 1 and part of the LDC group were obtained from the official UNFCCC website 9,10. The Global Climate Risk Index 201711 was used as a measure of country level climate vulnerability to extreme weather events. This metric was selected as providing the most recent, open access data on country level vulnerability. The Global Climate Risk Index rank was converted into five categories of risk (low, medium-low, medium, medium-high and high) using the same method as stated in the Germanwatch report ${ }^{11}$.

\section{Supplementary References}

1. Official UNFCCC portal at: http:/ / www4.unfccc.int/submissions/indc/Submission \%20Pages/submissions.aspx

2. Taiwan NDC available from: http://enews.epa.gov.tw/enews/enews_ftp/104/1117/174044/Submission\%20by\%20Re public \%20of\%20China \%20(Taiwan)Intended \%20Nationally \%20Determined \%20Contributi on.pdf

3. Neuendorf, K. A. The content analysis guidebook. Thousand Oaks, CA: Sage (2002)

4. Secretariat of the Convention on Biological Diversity (CBD). Connecting Biodiversity and Climate Change Mitigation and Adaptation: Report of the Second Ad Hoc Technical Expert Group 
on Biodiversity and Climate Change. (2009)

5. FEbA (Friends of Ecosystem-based Adaptation). Making Ecosystem-based Adaptation Effective: A Framework for Defining Qualification Criteria and Quality Standards. GIZ, Bonn, Germany, IIED, London, UK, and IUCN, Gland, Switzerland. 14 pp. (2017)

6. Johnson et al. An Overview of Readiness for REDD. A compilation of readiness activities prepared on behalf of the Forum on Readiness for REDD Version 2. The Woods Hole Research Centre (2009)

7. Palombi, L., \& Sessa, R. Climate-smart agriculture: sourcebook. Food and Agriculture Organization of the United Nations (FAO). Retrieved from http://www.fao.org/3/ai3325e.pdf (2013)

8. World Bank income classifications available at:

https:/ / datahelpdesk.worldbank.org/knowledgebase/articles/906519-world-bankcountry-and-lending-groups

9. UNFCCC classification of Annex 1 and non-Annex countries available at: http:/ / unfccc.int/parties_and_observers/parties/annex_i/items/2774.php

10. UNFCCC classification of LDC group available at: http://unfccc.int/cooperation_and_support/ldc/items/3097.ph

11. Kreft, S. et al. Global Climate Risk Index 2017. Retrieved from https://germanwatch.org/de/download/16411.pdf (2016) 


\section{Supplementary Tables}

Table S1 EbA visions in the NDCs: explicit and implicit recognition of the importance of EbA approaches

\begin{tabular}{ll}
\hline Nation & Evidence (i.e. specific statements in the adaptation component of the \\
& NDC) \\
\hline Argentina & The promotion of biodiversity conservation and adaptation based on \\
ecosystems
\end{tabular}




\begin{tabular}{|c|c|}
\hline $\begin{array}{l}\text { Burkina } \\
\text { Faso }\end{array}$ & $\begin{array}{l}\text { Sustainable rural production systems which, by taking into } \\
\text { consideration local knowledge and know-how... (iii) improve the } \\
\text { well-being of the people living on the land and (iv) restore preserve } \\
\text { the integrity and functioning of ecosystems." }\end{array}$ \\
\hline Cabo Verde & $\begin{array}{l}\text { Increasing adaptive capacities of the agro-silvo-pastoral production } \\
\text { systems in order to ensure and improve national food production, } \\
\text { and promoting Cabo Verde's blue economy; }\end{array}$ \\
\hline Cambodia & $\begin{array}{l}\text { Promoting and improving the adaptive capacity of communities, } \\
\text { especially through community based adaptation actions, and } \\
\text { restoring the natural ecology system to respond to climate change }\end{array}$ \\
\hline $\begin{array}{l}\text { Central } \\
\text { African } \\
\text { Republic }\end{array}$ & $\begin{array}{l}\text { Adaptation option 3: Sustainable management of the agricultural, } \\
\text { forestry and animal husbandry systems } \\
\text { Objective } 10 \text {. Promote agricultural and forestry systems and } \\
\text { sustainable soil management. } \\
\text { Objective 11. Promote urban, suburban and community forestry. } \\
\text { Objective 12. Restore degraded forest landscapes. }\end{array}$ \\
\hline Chile & $\begin{array}{l}\text { The National Forestry Corporation (CONAF) is implementing the } \\
\text { National Climate Change and Vegetation Resource Strategy. This } \\
\text { plan, proposes climate change mitigation and adaptation measures } \\
\text { aimed at supporting the recovery and protection of native lands and } \\
\text { xerophytes. In addition, it promotes the plantation of vegetation in } \\
\text { apt soils belonging to small and medium-sized producers. A state } \\
\text { mechanism will be designed and implemented to facilitate access by } \\
\text { communities and owners to the benefits associated with the } \\
\text { environmental services generated by these recovered ecosystems. }\end{array}$ \\
\hline Colombia & $\begin{array}{l}\text { Strategic lines: } \\
\text { Socio-ecosystem based adaptation with a view to move towards } \\
\text { economies, societies and ecosystems resilient to climate change } \\
\text { impacts }\end{array}$ \\
\hline Costa Rica & $\begin{array}{l}\text { The country will continue with its Green and Inclusive Development } \\
\text { policy through local actions in adaptation, such as, inter alia, the } \\
\text { strengthening of conservation programs and expanding the } \\
\text { environmental services payments program to include Ecosystem } \\
\text { based Adaptation. } \\
\text { Costa Rica is committed to develop its adaptation practice from an } \\
\text { ecosystem based adaptation focus, building on the commitment to } \\
\text { increase forest coverage to } 60 \% \text {. }\end{array}$ \\
\hline Djibouti & $\begin{array}{l}\text { As the country contains a number of already weakened ecosystems, } \\
\text { any work done to improve food security and water resources }\end{array}$ \\
\hline
\end{tabular}




\begin{tabular}{|c|c|}
\hline & $\begin{array}{l}\text { management will need to endeavour to preserve the environment } \\
\text { from a perspective of sustainable development }\end{array}$ \\
\hline $\begin{array}{l}\text { Dominican } \\
\text { Republic }\end{array}$ & $\begin{array}{l}\text { The elements of the strategic planning approach to adaptation are: } \\
\text { - Ecosystem-Based Adaptation/Resilience of Ecosystems }\end{array}$ \\
\hline Ecuador & $\begin{array}{l}\text { These articles determine that Nature, or "Pacha Mama", where life } \\
\text { transpires and is reproduced, has the right to integral respect for its } \\
\text { existence, maintenance and regeneration of its life cycles, structure, } \\
\text { functions and evolutionary processes; and that is has the right to } \\
\text { restoration, apart from the obligation of the State and natural persons } \\
\text { or legal entities to compensate individuals and communities that } \\
\text { depend on affected natural systems. } \\
\text { Objective 7: To guarantee the rights of nature and promote } \\
\text { environmental, sustainability globally. } \\
7.6 \text { : To manage water heritage sustainably and taking into account } \\
\text { participation of people, using a watershed and ecological flow } \\
\text { approach to ensure the human right to water. Ecosystem and forest } \\
\text { protection as well as the strengthening of the national protected areas } \\
\text { systems play a crucial role for the combat of climate change. }\end{array}$ \\
\hline Eritrea & $\begin{array}{l}\text { Being the most critical resources upon which the livelihoods for the } \\
\text { rural population of Eritrea depends, its conservation from all forms } \\
\text { of degradation is the priority of the government. }\end{array}$ \\
\hline Ethiopia & $\begin{array}{l}\text { Enhance the adaptive capacity of ecosystems, communities and } \\
\text { infrastructure through an ecosystem rehabilitation approach in the } \\
\text { highlands of Ethiopia. } \\
\text { Rehabilitation of degraded lands/forests will also increase } \\
\text { resilience of communities, infrastructures and ecosystems to } \\
\text { droughts and floods. }\end{array}$ \\
\hline Grenada & $\begin{array}{l}\text { Maintaining a healthy natural environment is also imperative as part } \\
\text { of Grenada's efforts to reduce vulnerability to climate change and } \\
\text { ecosystem based adaptation is a priority for Grenada }\end{array}$ \\
\hline Guatemala* & $\begin{array}{l}\text { Relevant actions include the implementation of the national } \\
\text { biodiversity strategy and its 2012-2022 action plan, which will allow } \\
\text { the integration of biodiversity into adaptation and mitigation to } \\
\text { climate change and the assessment of people's ancestral } \\
\text { (indigenous) knowledge, recognizing the role of farmer and } \\
\text { indigenous economic models, culturally relevant in adapting to } \\
\text { climate change }\end{array}$ \\
\hline Guinea & $\begin{array}{l}\text { Put in place the measures needed to protect, conserve and manage } \\
\text { ecosystems, revive economic activities and boost the resilience of } \\
\text { communities in its coastal zone. }\end{array}$ \\
\hline
\end{tabular}




\begin{tabular}{|c|c|}
\hline Guinea & It is therefore necessary and urgent that the Guinea-Bissau \\
\hline Bissau & $\begin{array}{l}\text { Government take initiatives such as the development of new, more } \\
\text { resistant, crops and changes in agricultural systems in order to } \\
\text { increase the resilience of its agriculture to climate change, the } \\
\text { protection of coastal ecosystems and adopt measures to reduce long } \\
\text { term risks, like the integration of climate change into local } \\
\text { development plans, forest management plans and soil occupancy } \\
\text { and, generally speaking, in development policies and strategies. } \\
\text { These changes are intended primarily to increase the food security of } \\
\text { populations of rural areas in order to enhance their adaptation } \\
\text { capacity, reducing pressure on forest and fishery resources and } \\
\text { improving access to safe water for human consumption and livestock }\end{array}$ \\
\hline Honduras* & $\begin{array}{l}\text { Because of the economic importance they represent for the country, as } \\
\text { the main source of livelihood for indigenous and Afro-Honduran } \\
\text { groups and other coastal communities, and because of their high } \\
\text { vulnerability, it is essential to implement strategies that promote / } \\
\text { Maintain the integrity and functioning of these ecosystems. }\end{array}$ \\
\hline Indonesia & $\begin{array}{l}\text { Promoting climate resilience in food, water and energy: Recognising } \\
\text { the need to fulfil the needs of a growing young population for food, } \\
\text { water and energy, Indonesia will improve its management of natural } \\
\text { resources to enhance climate resilience by protecting and restoring } \\
\text { key terrestrial, coastal and marine ecosystems. }\end{array}$ \\
\hline Lao PDR & $\begin{array}{l}\text { The forestry sector contributes to both national economy and also } \\
\text { livelihoods of many Laotians for example. Sustainable forest } \\
\text { management therefore improves the resilience of communities and } \\
\text { ecosystems and at the same time reduces GHG emissions by } \\
\text { absorbing carbon dioxide. }\end{array}$ \\
\hline Lebanon & $\begin{array}{l}\text { Overarching objective: Towards sustainably managed forest } \\
\text { resources, safeguarded ecological integrity, and economic and social } \\
\text { development for the benefit of present and future generations. }\end{array}$ \\
\hline Madagascar & $\begin{array}{l}\text { Moreover, the choice of the identified adaptation sectors (agriculture, } \\
\text { coastal zone management, human health), as well as ecosystem based } \\
\text { adaptation approach (forests, mangroves, biodiversity, water } \\
\text { resources) can have significant benefits on the mitigation. }\end{array}$ \\
\hline Malawi & $\begin{array}{l}\text { Climate change also requires farmers to adapt to new agronomic } \\
\text { practices such as conservation agriculture, growing of drought } \\
\text { tolerant crops, precision agriculture (which in turn also requires a } \\
\text { better access to input for seeds and fertilizers) and agro-forestry } \\
\text { amongst others in order to improve productivity. }\end{array}$ \\
\hline
\end{tabular}




\begin{tabular}{|c|c|}
\hline & $\begin{array}{l}\text { Forest regeneration could spur bee-keeping and indigenous } \\
\text { mushroom harvesting thereby taking people-off from forest } \\
\text { extractive activities }\end{array}$ \\
\hline Maldives & $\begin{array}{l}\text { Coral reefs are an important contributor the economy supporting } \\
\text { tourism and fisheries. The reefs support rich biodiversity providing } \\
\text { food and livelihoods to island communities. Coral reefs conservation } \\
\text { through ecosystem approach as an adaptation measure to increase the } \\
\text { resilience of the coral reef ecosystem }\end{array}$ \\
\hline Mexico & $\begin{array}{l}\text { Ecosystem-Based Adaptation: Ecosystem-based adaptation consists } \\
\text { of the conservation of biodiversity and ecosystem services as part of } \\
\text { an integral adaptation strategy to assist human communities to adapt } \\
\text { to the adverse effects of climate change. }\end{array}$ \\
\hline Morocco & $\begin{array}{l}\text { The protection of natural heritage, } \\
\text { biodiversity, forestry and fishery resources through an ecosystem- } \\
\text { based adaptation approach. }\end{array}$ \\
\hline Myanmar & $\begin{array}{l}\text { Eco-system based approaches to adaptation at township level will be } \\
\text { tested during the course of } 2016-18 \text {, including a vulnerability analysis } \\
\text { of the following elements: urban planning, infrastructure } \\
\text { development, environmental risk and livelihood patterns. }\end{array}$ \\
\hline Nepal & $\begin{array}{l}\text { It also aims to put in place forest carbon trade and payment } \\
\text { mechanism and mainstream community/ecosystem-based } \\
\text { adaptation by } 2025 \text {. }\end{array}$ \\
\hline Niue & $\begin{array}{l}\text { In addition to the NNSP and the Climate Change Policy there have } \\
\text { been a number of recent policies which have integrated climate } \\
\text { change considerations into the decision-making process. These } \\
\text { include the Forest Policy, the Niue National Energy Policy, and the } \\
\text { Ecosystems Approach to Fisheries Management. Furthermore, a } \\
\text { number of Government departments have incorporated climate } \\
\text { change policies into their corporate plans, for example the Agriculture } \\
\text { Sector Plan. }\end{array}$ \\
\hline Peru & $\begin{array}{l}\text { Forestry } \\
\text { - Scope: Considers protecting ecosystem services that forests } \\
\text { provide, and attend the most vulnerable groups (indigenous } \\
\text { communities and small forest producers). } \\
\text { - Intermediate objectives: Promote comprehensive land } \\
\text { management with a landscape approach, oriented to increase } \\
\text { forests resilience to climate change, and reduce the } \\
\text { vulnerability of local populations. }\end{array}$ \\
\hline
\end{tabular}




\begin{tabular}{|c|c|}
\hline $\begin{array}{l}\text { Saint } \\
\text { Vincent and } \\
\text { the } \\
\text { Grenadines }\end{array}$ & $\begin{array}{l}\text { Enhancing the adaptive capacity of rural economies and natural } \\
\text { resources to climate change through the management and protection } \\
\text { of land based natural resources and agricultural production systems. }\end{array}$ \\
\hline $\begin{array}{l}\text { Saudi } \\
\text { Arabia }\end{array}$ & $\begin{array}{l}\text { Develop and enhance arid and semi-arid rural areas through various } \\
\text { natural resource conservation activities, biodiversity and eco-system } \\
\text { based adaptation efforts. }\end{array}$ \\
\hline Seychelles & $\begin{array}{l}\text { Also recently, the Seychelles Biodiversity Strategy and Action Plan } \\
(2015-2020) \text { has been launched, and includes many cross-sectoral } \\
\text { projects with climate change adaptation implications. Projects address } \\
\text { issues such as sustainable tourism, watershed management, } \\
\text { sustainable agriculture and fisheries, disaster planning, research and } \\
\text { a shift toward ecosystem-based adaptation approaches to } \\
\text { biodiversity conservation }\end{array}$ \\
\hline Singapore & $\begin{array}{l}\text { Safeguarding biodiversity: Enriching Singapore's urban biodiversity } \\
\text { and extensive greenery is part of the national vision for a "City in a } \\
\text { Garden". Extensive roadside tree planting contributes to moderating } \\
\text { temperatures in the heart of the city. Over } 300 \text { parks and a network of } \\
\text { park connectors provide relief from the hot urban tropical climate. } \\
\text { Large freshwater bodies surrounded by forested catchments help to } \\
\text { ameliorate the urban island heat effect and conserve our rich natural } \\
\text { heritage of flora and fauna. Singapore recognises the need to track its } \\
\text { rich urban biodiversity in a manner which can integrate conservation } \\
\text { and adaptation actions. }\end{array}$ \\
\hline $\begin{array}{l}\text { Solomon } \\
\text { Islands }\end{array}$ & $\begin{array}{l}\text { In the area around the capital city of Honiara a general decline per } \\
\text { decade is occurring while the population is growing at a rate of } \\
\text { approximately } 6 \% \text { per annum. To ensure adequate water supply for } \\
\text { the growing population of the city a robust and well enforced } \\
\text { Integrated Water Resource Management strategy and programme } \\
\text { needs to be put in place. Conservation and effective management of } \\
\text { the forests surrounding Honiara is essential }\end{array}$ \\
\hline $\begin{array}{l}\text { South } \\
\text { Sudan }\end{array}$ & $\begin{array}{l}\text { Ecosystem-based adaptation consists of the conservation of } \\
\text { biodiversity and ecosystem services as part of an integrated } \\
\text { adaptation strategy to assist human communities to adapt to the } \\
\text { adverse effects of climate change }\end{array}$ \\
\hline Swaziland & $\begin{array}{l}\text { Enhance biodiversity and promote ecotourism with benefit sharing } \\
\text { for the surrounding communities. }\end{array}$ \\
\hline Thailand & $\begin{array}{l}\text { Safeguard food security through the guidance of Sufficiency } \\
\text { Economy Philosophy e.g. an application of the New Theory in } \\
\text { agriculture and land management to promote appropriate resource }\end{array}$ \\
\hline
\end{tabular}




\begin{tabular}{|c|c|}
\hline & $\begin{array}{l}\text { allocation and economic diversification at the household level and } \\
\text { sustainable management of community forests to promote food } \\
\text { security at the community level, for instance. }\end{array}$ \\
\hline Tonga & $\begin{array}{l}\text { Promoting reforestation and rehabilitation of cleared and degraded } \\
\text { forests with climate change resilient, and ecologically and socially } \\
\text { appropriate tree species; }\end{array}$ \\
\hline $\begin{array}{l}\text { United } \\
\text { Arab } \\
\text { Emirates }\end{array}$ & $\begin{array}{l}\text { The UAE is also undergoing significant restoration and plantation } \\
\text { efforts of both mangroves and sea-grass, supporting ecosystem- } \\
\text { based adaptation as well. }\end{array}$ \\
\hline Uruguay & $\begin{array}{l}\text { Promote ecosystem-based adaptation, strengthening ecosystem and } \\
\text { biodiversity conservation strategies. }\end{array}$ \\
\hline Vanuatu & $\begin{array}{l}\text { These strategic priorities from } 2015 \text { to } 2020 \text { include the need for: } \\
\text {.. Ecosystem based approaches }\end{array}$ \\
\hline Venezuela* & $\begin{array}{l}\text { These instruments represent the methodological, conceptual and } \\
\text { policy framework aligned country project for the sovereign exercise of } \\
\text { conservation and sustainable use of Diversity Biological, thus } \\
\text { reducing the vulnerability to multiple adverse effects of climate } \\
\text { change } \\
\text { Promote and develop a of rights of Mother Earth as representing the } \\
\text { rights of generations present and future, as well as respect for other } \\
\text { life forms }\end{array}$ \\
\hline Vietnam & $\begin{array}{l}\text { Implement ecosystem-based adaptation through the } \\
\text { development of ecosystem services and biodiversity } \\
\text { conservation, with a focus on the preservation of genetic } \\
\text { resources, species at risk of extinction, and important } \\
\text { ecosystems }\end{array}$ \\
\hline Yemen & $\begin{array}{l}\text { Additional support will also needed on issues relating to } \\
\text { Climate Change Adaptation (CCA) and Disaster Risk Reduction } \\
\text { (DRR) as well as Ecosystem-Based Adaptation (EBA) including } \\
\text { on sustainable management of natural resource }\end{array}$ \\
\hline Zimbabwe & $\begin{array}{l}\text { Promoting non-timber forest products and sustainable agro-forestry } \\
\text { practices to enhance forest-based adaptation. } \\
\text { Strengthening biodiversity conservation management and integrity of } \\
\text { natural ecosystems to adapt to climate change. }\end{array}$ \\
\hline
\end{tabular}

*Denotes a translation by the authors from the native language in the NDC to English 
Table S2 EbA actions in the NDCs coded by strength, ecosystem type, and timescale

\begin{tabular}{|c|c|c|c|c|}
\hline Country & $\begin{array}{l}\text { Basic or } \\
\text { Robust } \\
\text { EbA } \\
\text { Action }\end{array}$ & $\begin{array}{l}\text { Type of } \\
\text { ecosystem or } \\
\text { agroforestry }\end{array}$ & $\begin{array}{l}\text { Current or } \\
\text { planned } \\
\text { action }\end{array}$ & $\begin{array}{l}\text { Evidence (i.e. specific statements in the } \\
\text { adaptation component of the NDC) }\end{array}$ \\
\hline Afghanistan & Basic & $\begin{array}{l}\text { River } \\
\text { catchments }\end{array}$ & Planned & $\begin{array}{l}\text { Planning for proper watershed } \\
\text { management and promoted through } \\
\text { community-based natural resources } \\
\text { management }\end{array}$ \\
\hline \multirow{3}{*}{ Afghanistan } & \multirow{3}{*}{ Basic } & \multirow{3}{*}{$\begin{array}{l}\text { Terrestrial } \\
\text { forests or } \\
\text { woodlands, } \\
\text { Grasslands } \\
\text { and } \\
\text { rangelands }\end{array}$} & \multirow{3}{*}{ Planned } & $\begin{array}{l}\text { Action: Regeneration of at least } 40 \% \text { of } \\
\text { existing degraded forests and rangeland } \\
\text { areas (the area covered will be } \\
\text { approximately } 232,050 \text { ha for forestry; and } \\
5.35 \text { million ha for rangelands). }\end{array}$ \\
\hline & & & & $\begin{array}{l}\text { Capacity building needs: Practitioners } \\
\text { group built in university, government and } \\
\text { local delivery levels }\end{array}$ \\
\hline & & & & Finance needs (USD): 2.5 Billion \\
\hline \multirow{4}{*}{ Angola } & \multirow{4}{*}{ Basic } & \multirow{4}{*}{$\begin{array}{l}\text { Grasslands } \\
\text { and } \\
\text { rangelands }\end{array}$} & \multirow{4}{*}{ Current } & $\begin{array}{l}\text { Project title: Land Rehabilitation and } \\
\text { Grasslands and rangelandss Management } \\
\text { in Small Holders Agropastoral Production } \\
\text { Systems in Southwestern Angola (Project } \\
\text { RETESA). }\end{array}$ \\
\hline & & & & $\begin{array}{l}\text { Description: To enhance the capacity of } \\
\text { southwestern Angola's smallholder agro- } \\
\text { pastoral sector to mitigate the impact of } \\
\text { land degradation processes and to } \\
\text { rehabilitate degraded lands by } \\
\text { mainstreaming SLM technologies into } \\
\text { agro-pastoral and agricultural } \\
\text { development initiatives. }\end{array}$ \\
\hline & & & & $\begin{array}{l}\text { Total project cost (US \$ million): } 15.397 \text {. } \\
\text { Implementing GEF agency: FAO }\end{array}$ \\
\hline & & & & Sector: Land rehabilitation, Agriculture \\
\hline Angola & Basic & Agroforestry & Current & $\begin{array}{l}\text { The project will disseminate sustainable } \\
\text { land management and adaptation } \\
\text { practices in agro-forestry and land ecology } \\
\text { in } 350 \text { communities }\end{array}$ \\
\hline
\end{tabular}




\begin{tabular}{|c|c|c|c|c|}
\hline Bangladesh & Basic & $\begin{array}{l}\text { Terrestrial } \\
\text { forests or } \\
\text { woodlands }\end{array}$ & Current & $\begin{array}{l}\text { Project: Revegetation of Madhupur Forest } \\
\text { Through Rehabilitation of Forest } \\
\text { Dependent Local and Ethnic Communities }\end{array}$ \\
\hline Bangladesh & Basic & General & Current & $\begin{array}{l}\text { Project: Community Based Adaptation in } \\
\text { the Ecologically Critical Areas Through } \\
\text { Biodiversity Conservation and Social } \\
\text { Protection }\end{array}$ \\
\hline & & Terrestrial & & $\begin{array}{l}\text { Sustainable forest management and } \\
\text { conservation of biodiversity to ensure } \\
\text { sustained environmental services through: }\end{array}$ \\
\hline Bhutan & Basic & $\begin{array}{l}\text { forests or } \\
\text { woodlands }\end{array}$ & Planned & $\begin{array}{l}\text { Sustainable management of forest } \\
\text { management units (FMUs), protected } \\
\text { areas, community forests, forest areas } \\
\text { outside FMUs, and private forests }\end{array}$ \\
\hline \multirow{7}{*}{ Bolivia } & \multirow{7}{*}{ Robust } & \multirow{7}{*}{ Agroforestry } & \multirow{7}{*}{ Planned } & Consolidation of agroforestry systems. \\
\hline & & & & $\begin{array}{l}\text { Transition to semi-intensive systems of } \\
\text { livestock management and integrated } \\
\text { management of agroforestry and } \\
\text { silviculture techniques. }\end{array}$ \\
\hline & & & & $\begin{array}{l}\text { Strengthening community based } \\
\text { stewardship in forest management and } \\
\text { farming systems. }\end{array}$ \\
\hline & & & & $\begin{array}{l}\text { Reduction of vulnerabilities in } \\
\text { agricultural, fisheries, and agro-forestry } \\
\text { systems of production. }\end{array}$ \\
\hline & & & & $\begin{array}{l}\text { Measures of agricultural and livestock } \\
\text { production insurance to include additional } \\
\text { conservation actions, making resilient } \\
\text { agricultural and forestry production } \\
\text { systems. }\end{array}$ \\
\hline & & & & $\begin{array}{l}\text { Resilience has been achieved through the } \\
\text { strengthening of environmental functions } \\
\text { and the productive capacities of } \\
\text { agricultural and agroforestry systems. }\end{array}$ \\
\hline & & & & $\begin{array}{l}\text { Timber and non-timber production has } \\
\text { increased by } 40 \% \text {, doubling food } \\
\text { production from the integrated } \\
\text { management of forest and agricultural } \\
\text { systems in } 2030 \text {. }\end{array}$ \\
\hline
\end{tabular}




\begin{tabular}{|c|c|c|c|c|}
\hline \multirow{8}{*}{ Bolivia } & \multirow{8}{*}{ Robust } & \multirow{8}{*}{$\begin{array}{l}\text { Terrestrial } \\
\text { forests or } \\
\text { woodlands }\end{array}$} & \multirow{8}{*}{ Planned } & $\begin{array}{l}\text { Increased forest areas with integrated and } \\
\text { sustainable community management } \\
\text { approaches with } 16.9 \text { million hectares in } \\
2030 \text {, in reference to } 3.1 \text { million hectares by } \\
2010 \text {. }\end{array}$ \\
\hline & & & & $\begin{array}{l}\text { Strengthened environmental functions } \\
\text { (carbon capture and storage, organic } \\
\text { matter and soil fertility, biodiversity } \\
\text { conservation and water availability) in } \\
\text { about } 29 \text { million hectares by } 2030 .\end{array}$ \\
\hline & & & & $\begin{array}{l}\text { Contribution to Gross Domestic Product } \\
\text { (GDP) growth of } 5.4 \% \text { in } 2030 \text {, boosted by } \\
\text { agricultural and forestry production } \\
\text { complementary to conservation. }\end{array}$ \\
\hline & & & & $\begin{array}{l}\text { Reducing extreme poverty to zero in the } \\
\text { population dependent on forests by } 2030 \text {, } \\
\text { based on approximately } 350 \text { thousand } \\
\text { people by } 2010 \text {. }\end{array}$ \\
\hline & & & & $\begin{array}{l}\text { Joint mitigation and adaptation capacity } \\
\text { has increased in areas covered by forests, } \\
\text { agricultural and forestry systems from } 0.35 \\
\text { units in } 2010 \text { to } 0.78 \text { in } 2030 \text {, as measured } \\
\text { by the Index of Sustainable Forest Life, } \\
\text { achieving productivity and conservation } \\
\text { systems that are both complementary and } \\
\text { resilient. }\end{array}$ \\
\hline & & & & $\begin{array}{l}\text { Community forest management has } \\
\text { increased sevenfold in the area of forest } \\
\text { management in } 2030 \text {. }\end{array}$ \\
\hline & & & & $\begin{array}{l}\text { Increased reforestation by } 6 \text { million } \\
\text { hectares by } 2030 \text {. }\end{array}$ \\
\hline & & & & $\begin{array}{l}\text { Integrated and sustainable management of } \\
\text { forests has strengthened through the } \\
\text { management of timber and non-timber } \\
\text { products in an integrated and sustainable } \\
\text { manner. }\end{array}$ \\
\hline $\begin{array}{l}\text { Burkina } \\
\text { Faso }\end{array}$ & Robust & $\begin{array}{l}\text { Terrestrial } \\
\text { forests or } \\
\text { woodlands }\end{array}$ & Planned & $\begin{array}{l}12 \text { regions }(\mathrm{CT}) \text { or } 180 \text { communes, in } \\
\text { cooperation with grassroots communities, } \\
\text { create and organise one biodiversity } \\
\text { conservation area each with a commune or }\end{array}$ \\
\hline
\end{tabular}




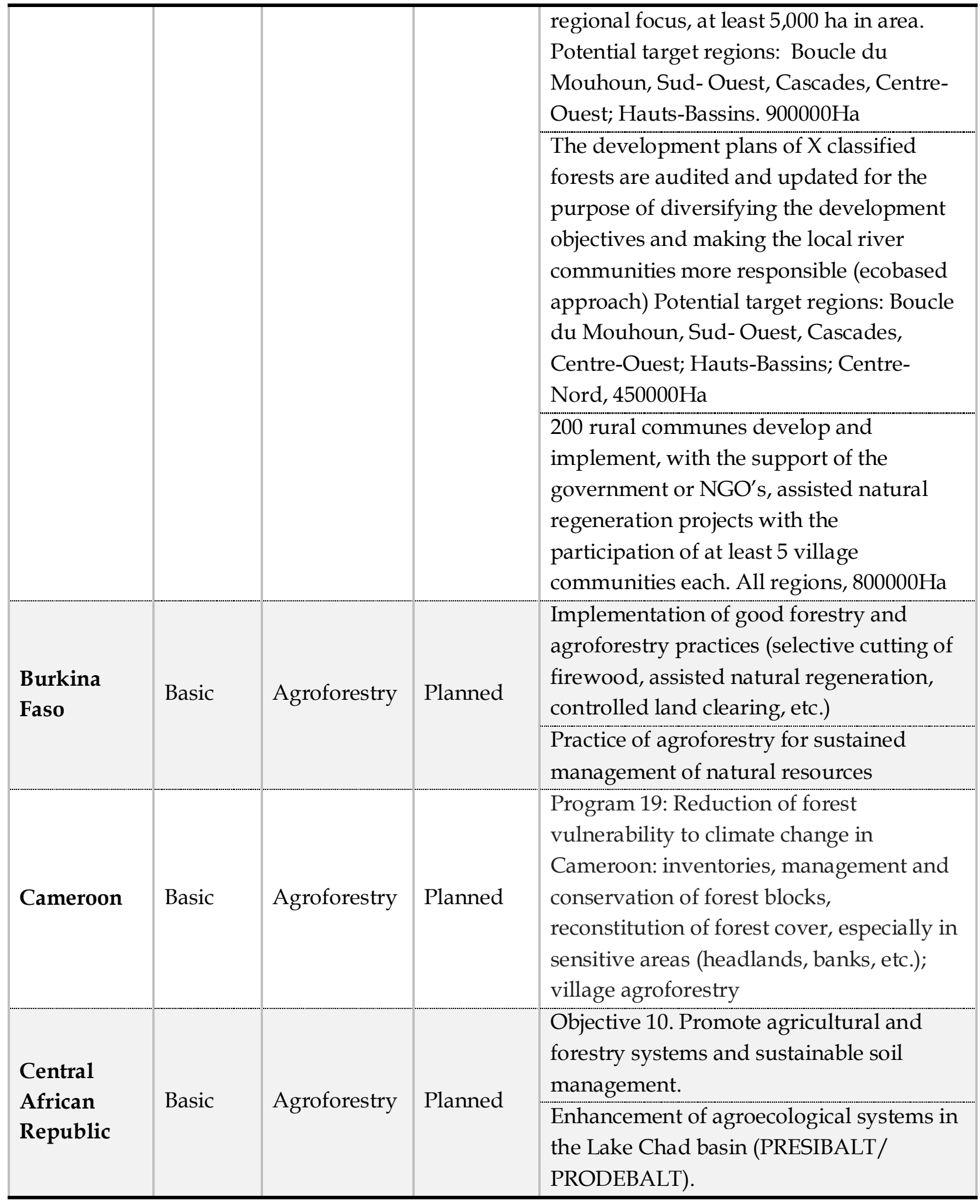




\begin{tabular}{|c|c|c|c|c|}
\hline $\begin{array}{l}\text { Central } \\
\text { African } \\
\text { Republic }\end{array}$ & Basic & $\begin{array}{l}\text { Terrestrial } \\
\text { forests or } \\
\text { woodlands }\end{array}$ & Planned & $\begin{array}{l}\text { Objective } 11 . \text { Promote urban, suburban } \\
\text { and community forestry. }\end{array}$ \\
\hline \multirow[t]{2}{*}{ Chad } & \multirow[t]{2}{*}{ Basic } & \multirow[t]{2}{*}{ Agroforestry } & \multirow[t]{2}{*}{ Planned } & $\begin{array}{l}\text { Agriculture: develop intensive and diverse } \\
\text { cultivation, using improved inputs, } \\
\text { (organic fertilisers including composts, } \\
\text { adapted plant varieties), agroforestry, land } \\
\text { and water conservation, (implementation } \\
\text { of soil restoration works) and preparation } \\
\text { and distribution of new cropping } \\
\text { calendars }\end{array}$ \\
\hline & & & & $\begin{array}{l}\text { Develop an agro-ecological approach (soil } \\
\text { fertility management practices, addition of } \\
\text { manure and compost, agroforestry } \\
\text { development, water and soil conservation) }\end{array}$ \\
\hline \multirow[b]{2}{*}{ Chad } & \multirow[b]{2}{*}{ Basic } & \multirow[b]{2}{*}{$\begin{array}{l}\text { Grasslands } \\
\text { and } \\
\text { rangelands }\end{array}$} & \multirow[b]{2}{*}{ Current } & $\begin{array}{l}\text { Soil restoration and defence against } \\
\text { degradation caused by climate change }\end{array}$ \\
\hline & & & & $\begin{array}{l}\text { Improvement of intercommunity } \\
\text { grassland areas, in order to reduce } \\
\text { migratory movements due to climate } \\
\text { change }\end{array}$ \\
\hline \multirow[b]{2}{*}{ Colombia } & \multirow[b]{2}{*}{ Basic } & \multirow[b]{2}{*}{ General } & \multirow[b]{2}{*}{ Planned } & $\begin{array}{l}\text { The following are the specific prioritized } \\
\text { actions by } 2030 \text { in Colombia: }\end{array}$ \\
\hline & & & & $\begin{array}{l}\text { Increase of more than } 2.5 \text { million hectares } \\
\text { in coverage of newly protected areas in the } \\
\text { National System of Protected Areas } \\
\text { (SINAP), in coordination with local and } \\
\text { regional stakeholders }\end{array}$ \\
\hline \multirow{3}{*}{ Congo, Rep } & \multirow{3}{*}{ Robust } & \multirow{3}{*}{$\begin{array}{l}\text { Coastal and } \\
\text { marine } \\
\text { habitats }\end{array}$} & \multirow{3}{*}{ Planned } & $\begin{array}{l}\text { The promotion of income-generating } \\
\text { activities related to marine and coastal } \\
\text { ecosystems. }\end{array}$ \\
\hline & & & & $\begin{array}{l}\text { A scheme including mangrove } \\
\text { conservation projects for coastal } \\
\text { protection, protection of species, } \\
\text { establishment of specific facilities for the } \\
\text { reception and management of waste, } \\
\text { monitoring of nesting turtles }\end{array}$ \\
\hline & & & & $\begin{array}{l}\text { Creation of a coastal and marine } \\
\text { environment observatory. }\end{array}$ \\
\hline
\end{tabular}




\begin{tabular}{|c|c|c|c|c|}
\hline Costa Rica & Basic & $\begin{array}{l}\text { Agroforestry, } \\
\text { River } \\
\text { catchments }\end{array}$ & Current & $\begin{array}{l}\text { Integral environment management } \\
\text { through agro-forestry systems and } \\
\text { watershed management, the adaptive co- } \\
\text { management at the watershed level }\end{array}$ \\
\hline Costa Rica & Basic & $\begin{array}{l}\text { Terrestrial } \\
\text { forests or } \\
\text { woodlands }\end{array}$ & Planned & $\begin{array}{l}\text { Costa Rica is committed to develop its } \\
\text { adaptation practice from an ecosystem } \\
\text { based adaptation focus, building on the } \\
\text { commitment to increase forest coverage to } \\
60 \% \text {. }\end{array}$ \\
\hline Costa Rica & Basic & $\begin{array}{l}\text { Terrestrial } \\
\text { forests or } \\
\text { woodlands, } \\
\text { River } \\
\text { catchments }\end{array}$ & Planned & $\begin{array}{l}\text { There are opportunities for exploring } \\
\text { synergies between adaptation practices } \\
\text { and the reduction of emissions through } \\
\text { avoided deforestation. These include, inter } \\
\text { alia, the consolidation of FONAFIFO's } \\
\text { Environmental Services Payments } \\
\text { program and the Forest Certification } \\
\text { program as a mechanism to promote the } \\
\text { sustainable development forest resources } \\
\text { and effective protection of water sources } \\
\text { for all } 81 \text { counties of Costa Rica; the } \\
\text { promotion of the National Biological } \\
\text { Corridor System and the National } \\
\text { Protected Areas System (SINAC). }\end{array}$ \\
\hline $\begin{array}{l}\text { Cote } \\
d^{\prime} \text { Ivoire }\end{array}$ & Basic & Agroforestry & Planned & $\begin{array}{l}\text { Forestry and land use: improving } \\
\text { silvicultural species, promoting } \\
\text { reforestation and agro-ecology, restoring } \\
\text { degraded land, promoting techniques for } \\
\text { improving fertility and soil conservation }\end{array}$ \\
\hline & & & & $\begin{array}{l}\text { Support programme to reduce } \\
\text { vulnerability in coastal fishing areas } \\
\text { (PRAREV-PECHE) }\end{array}$ \\
\hline Djibouti & Robust & $\begin{array}{l}\text { Coastal and } \\
\text { marine } \\
\text { habitats }\end{array}$ & Current & $\begin{array}{l}\text { The programme's overarching objective is } \\
\text { to support the populations in rural coastal } \\
\text { zones affected by climate change in order } \\
\text { to improve their resilience, reduce their } \\
\text { vulnerability to such changes and promote } \\
\text { the co-management of marine resources. } \\
\text { The rehabilitation of mangroves will } \\
\text { enhance their role as a shield for coastal } \\
\text { protection against the tides and erosion. In }\end{array}$ \\
\hline
\end{tabular}




\begin{tabular}{|c|c|c|c|c|}
\hline & & & & $\begin{array}{l}\text { addition, the restoration of coral reefs and } \\
\text { mangroves will generate additional } \\
\text { revenue through the development of } \\
\text { ecotourism activities. }\end{array}$ \\
\hline \multirow{3}{*}{ Djibouti } & \multirow{3}{*}{ Basic } & \multirow{3}{*}{$\begin{array}{l}\text { Coastal and } \\
\text { marine } \\
\text { habitats }\end{array}$} & \multirow{3}{*}{ Current } & $\begin{array}{l}\text { Implementation of priority NAPA actions } \\
\text { to strengthen resilience in Djibouti's most } \\
\text { vulnerable coastal zones }\end{array}$ \\
\hline & & & & $\begin{array}{l}\text { The project will adopt an integrated } \\
\text { approach that combines local actions to } \\
\text { improve the resilience of the communities } \\
\text { and the ecosystems with central actions to } \\
\text { remove any key political and institutional } \\
\text { obstacles. The project includes activities } \\
\text { grouped together into three components, } \\
\text { corresponding to the priorities defined in } \\
\text { the National Adaptation Programme of } \\
\text { Action (NAPA): i) policy; ii) ecosystem } \\
\text { rehabilitation; and iii) climate forecasts } \\
\text { and the prevention of catastrophes. }\end{array}$ \\
\hline & & & & $\begin{array}{l}\text { Launched in 2011, this project focuses on } \\
\text { two rural coastal communities, Khor } \\
\text { Angar and Damerjog. }\end{array}$ \\
\hline \multirow{6}{*}{ Djibouti } & \multirow{6}{*}{ Robust } & \multirow{6}{*}{$\begin{array}{l}\text { Coastal and } \\
\text { marine } \\
\text { habitats }\end{array}$} & \multirow{6}{*}{ Planned } & $\begin{array}{l}\text { Implementing Adaptation Technologies in } \\
\text { the Fragile Ecosystems of the Tadjourah } \\
\text { and Hanlé Plains }\end{array}$ \\
\hline & & & & $\begin{array}{l}\text { The project's objective is to set up climate } \\
\text { change adaptation measures to protect and } \\
\text { enhance the resilience of the local } \\
\text { communities and the ecosystems in the } \\
\text { Tadjourah and Hanlé Regions. }\end{array}$ \\
\hline & & & & $\begin{array}{l}\text { Component 1: Protection against water- } \\
\text { related climate change; }\end{array}$ \\
\hline & & & & $\begin{array}{l}\text { Component 2: Rehabilitation of } \\
\text { ecosystems (plant cover in Hanlé and } \\
\text { Tadjourah, and mangroves in the coastal } \\
\text { zone of Tadjourah); }\end{array}$ \\
\hline & & & & $\begin{array}{l}\text { Component 3: Sustainable, resistant means } \\
\text { of subsistence; }\end{array}$ \\
\hline & & & & $\begin{array}{l}\text { Component } 4 \text { : Incorporation of adaptation } \\
\text { to climate change as part of the }\end{array}$ \\
\hline
\end{tabular}




\begin{tabular}{|c|c|c|c|c|}
\hline & & & & $\begin{array}{l}\text { development and resilience of the } \\
\text { communities. }\end{array}$ \\
\hline Ecuador & Basic & Agroforestry & Current & $\begin{array}{l}\text { Measures including the application of } \\
\text { silvopasture systems; the incorporation of } \\
\text { climate change adaptation systems in the } \\
\text { zoning of rural areas; the creation of } \\
\text { germoplasm banks, the use of species that } \\
\text { contribute to decreasing erosion; } \\
\text { diversification of species more resistant to } \\
\text { climate change; among others. }\end{array}$ \\
\hline El Salvador & Basic & Agroforestry & Planned & $\begin{array}{l}\text { By 2030, El Salvador will establish and } \\
\text { manage one million hectares through } \\
\text { "Sustainable Landscapes Resilient to } \\
\text { Climate Change". This is an integrated } \\
\text { approach to landscape restoration, where } \\
\text { forest areas will be rehabilitated and } \\
\text { conserved, biological corridors will be } \\
\text { established through the adoption of } \\
\text { resilient agroforestry systems and } \\
\text { transformation of agricultural areas with } \\
\text { low carbon sustainable practices, and } \\
\text { seeking Neutrality in Degradation of the } \\
\text { Lands. In this framework, the current tree } \\
\text { cover - } 27 \% \text { of the territory - will be } \\
\text { conserved - maintaining natural areas, } \\
\text { including mangroves, agroforestry } \\
\text { systems and existing forest plantations. In } \\
\text { addition, forest carbon stocks will be } \\
\text { improved, increasing coverage in } 25 \% \text { of } \\
\text { the territory, with agroforestry systems } \\
\text { and reforestation activities in critical areas } \\
\text { such as gallery forests, water recharge } \\
\text { areas, and landslide areas. }\end{array}$ \\
\hline \multirow{3}{*}{ Eritrea } & \multirow{3}{*}{ Basic } & \multirow{3}{*}{ Agroforestry } & \multirow{3}{*}{ Planned } & $\begin{array}{l}\text { Promotion of Conservation } \\
\text { Agriculture/Climate Smart Agriculture in } \\
5 \% \text { of the cultivable land }\end{array}$ \\
\hline & & & & $\begin{array}{l}\text { Rehabilitations degraded land program for } \\
\text { agriculture over } 250,000 \text { ha; }\end{array}$ \\
\hline & & & & $\begin{array}{l}\text { (within "Intended Adaptation Goals for } \\
\text { 2030" section) }\end{array}$ \\
\hline
\end{tabular}




\begin{tabular}{|c|c|c|c|c|}
\hline Ethiopia & Robust & $\begin{array}{l}\text { Agroforestry, } \\
\text { Terrestrial } \\
\text { forests or } \\
\text { woodlands }\end{array}$ & Planned & $\begin{array}{l}\text { Improve and diversify economic } \\
\text { opportunities from agroforestry and } \\
\text { sustainable afforestation of degraded } \\
\text { forest areas. }\end{array}$ \\
\hline Ethiopia & Robust & $\begin{array}{l}\text { Terrestrial } \\
\text { forests or } \\
\text { woodlands, } \\
\text { Montane } \\
\text { habitats }\end{array}$ & Planned & $\begin{array}{l}\text { Enhance the adaptive capacity of } \\
\text { ecosystems, communities and } \\
\text { infrastructure through an ecosystem } \\
\text { rehabilitation approach in the highlands of } \\
\text { Ethiopia. Rehabilitation of degraded } \\
\text { lands/forests will also increase resilience } \\
\text { of communities, infrastructures and } \\
\text { ecosystems to droughts and floods. }\end{array}$ \\
\hline Gabon & Basic & $\begin{array}{l}\text { Coastal and } \\
\text { marine } \\
\text { habitats }\end{array}$ & Planned & $\begin{array}{l}\text { In addition, the general orientations of this } \\
\text { strategy call for the implementation of a } \\
\text { management plan for the coastal urban } \\
\text { environment and the promotion of } \\
\text { income-generating activities linked to } \\
\text { marine and coastal ecosystems. To this } \\
\text { must be added a scheme including } \\
\text { mangrove conservation projects for coastal } \\
\text { protection, protection of species, } \\
\text { establishment of specific facilities for the } \\
\text { reception and management of waste, } \\
\text { monitoring of nesting of turtles and the } \\
\text { creation of a coastal and marine } \\
\text { environment observatory. }\end{array}$ \\
\hline Ghana & Basic & Agroforestry & Planned & $\begin{array}{l}\text { Modified community-based conservation } \\
\text { agriculture adopted in } 43 \text { administrative } \\
\text { districts }\end{array}$ \\
\hline Grenada & Robust & $\begin{array}{l}\text { Coastal and } \\
\text { marine } \\
\text { habitats }\end{array}$ & Current & $\begin{array}{l}\text { Grenada is in the advanced stages of } \\
\text { developing its integrated coastal zone } \\
\text { management policy and management } \\
\text { system with the aim of facilitating } \\
\text { integrative planning and management } \\
\text { processes with the view to preserving and } \\
\text { enhancing coastal ecosystems and } \\
\text { ecosystem services while enabling social } \\
\text { and economic development. As part of the } \\
\text { policy development Grenada is also } \\
\text { undertaking several community ecosystem }\end{array}$ \\
\hline
\end{tabular}




\begin{tabular}{|c|c|c|c|c|}
\hline & & & & $\begin{array}{l}\text { based adaptation actions including coral } \\
\text { restoration, mangrove rehabilitation, all } \\
\text { with alternative livelihood implications }\end{array}$ \\
\hline \multirow{4}{*}{ Guinea } & \multirow{4}{*}{ Basic } & \multirow{4}{*}{$\begin{array}{l}\text { Coastal and } \\
\text { marine } \\
\text { habitats }\end{array}$} & \multirow{4}{*}{ Planned } & $\begin{array}{l}\text { Update the Mangrove Management and } \\
\text { Development Plan (SDAM); }\end{array}$ \\
\hline & & & & $\begin{array}{l}\text { Reduce the sources of mangrove } \\
\text { degradation; }\end{array}$ \\
\hline & & & & $\begin{array}{l}\text { Include adaptation in local development } \\
\text { plans and spatial planning tools; }\end{array}$ \\
\hline & & & & $\begin{array}{l}\text { Development of agro-ecological fish- } \\
\text { farming techniques; }\end{array}$ \\
\hline \multirow{3}{*}{ Guinea } & \multirow{3}{*}{ Robust } & \multirow{3}{*}{ Agroforestry } & \multirow{3}{*}{ Planned } & $\begin{array}{l}\text { Support the adaptation efforts of rural } \\
\text { communities to develop agro-sylvo- } \\
\text { pastoral techniques enabling them both to } \\
\text { continue their activities and preserve the } \\
\text { resources on which they rely }\end{array}$ \\
\hline & & & & $\begin{array}{l}\text { Development of techniques to conserve } \\
\text { and process agricultural, forestry and fish- } \\
\text { farming products; }\end{array}$ \\
\hline & & & & $\begin{array}{l}\text { Better management of pastoralism, } \\
\text { especially transnational pastoralism, so as } \\
\text { to limit degradation of grazing and soil } \\
\text { and reduce the risks of usage conflicts. }\end{array}$ \\
\hline $\begin{array}{l}\text { Guinea- } \\
\text { Bissau }\end{array}$ & Basic & Agroforestry & Planned & $\begin{array}{l}\text { Develop a national reforestation and } \\
\text { sustainable management of forest and agro } \\
\text { forestry ecosystems programme by } 2025 ;\end{array}$ \\
\hline Haiti & Basic & $\begin{array}{l}\text { Coastal and } \\
\text { marine } \\
\text { habitats }\end{array}$ & Planned & $\begin{array}{l}\text { Support to community management of } \\
\text { marine protected areas. }\end{array}$ \\
\hline \multirow{3}{*}{ Haiti } & \multirow{3}{*}{ Robust } & \multirow{3}{*}{$\begin{array}{l}\text { River } \\
\text { catchments }\end{array}$} & \multirow{3}{*}{ Planned } & $\begin{array}{l}\text { Development of payment initiatives for } \\
\text { Ecosystems services in watersheds. }\end{array}$ \\
\hline & & & & $\begin{array}{l}\text { Regulation of water flow, protection and } \\
\text { restoration of soils. }\end{array}$ \\
\hline & & & & $\begin{array}{l}\text { Development of } 15 \text { strategic watersheds } \\
\text { from Co-management. }\end{array}$ \\
\hline \multirow[b]{2}{*}{ Honduras } & \multirow[b]{2}{*}{ Basic } & \multirow[b]{2}{*}{ Agroforestry } & \multirow[b]{2}{*}{ Planned } & Agroforestry Law for Rural Development \\
\hline & & & & $\begin{array}{l}\text { Change in agricultural practices: } \\
\text { implementation of agroforestry systems } \\
\text { "Quesungual"; measures to combat }\end{array}$ \\
\hline
\end{tabular}




\begin{tabular}{|c|c|c|c|c|}
\hline & & & & $\begin{array}{l}\text { erosion; development of sustainable } \\
\text { systems based on agroecology. }\end{array}$ \\
\hline India & Basic & Agroforestry & Current & $\begin{array}{l}\text { National Agroforestry Policy (NAP) of } \\
\text { India aims at encouraging and expanding } \\
\text { tree plantation in complementarity and } \\
\text { integrated manner with crops and } \\
\text { livestock. It will help protect and stabilize } \\
\text { ecosystems, and promote resilient } \\
\text { cropping and farming systems to } \\
\text { minimize the risk during extreme climatic } \\
\text { events. It will also complement achieving } \\
\text { the target of increasing forest/ tree cover. }\end{array}$ \\
\hline India & Robust & $\begin{array}{l}\text { Coastal and } \\
\text { marine } \\
\text { habitats }\end{array}$ & Current & $\begin{array}{l}\text { The Government notified the Island } \\
\text { Protection Zone (IPZ) in } 2011 \text { with the } \\
\text { objective of ensuring livelihood security to } \\
\text { the local communities, conserving and } \\
\text { protecting coastal stretches, and } \\
\text { promoting development in a sustainable } \\
\text { manner. The IPZ focuses on disaster risk } \\
\text { reduction through bioshields with local } \\
\text { vegetation (mangroves) and other soft } \\
\text { protection measures, and the conservation } \\
\text { of beaches and sand dunes. }\end{array}$ \\
\hline India & Robust & $\begin{array}{l}\text { Montane } \\
\text { habitats }\end{array}$ & Current & $\begin{array}{l}\text { The National Mission for Sustaining the } \\
\text { Himalayan Ecosystem (NMSHE) } \\
\text { addresses important issues concerning } \\
\text { Himalayan Glaciers and the associated } \\
\text { hydrological consequences, biodiversity } \\
\text { and wildlife conservation and protection, } \\
\text { traditional knowledge societies and their } \\
\text { livelihood and planning for sustaining of } \\
\text { the Himalayan Ecosystem. Government } \\
\text { has also launched National Mission on } \\
\text { Himalayan Studies to complement } \\
\text { NMSHE with the objective of building a } \\
\text { body of scientific and traditional } \\
\text { knowledge along with demonstrating } \\
\text { replicable solutions to the problems in } \\
\text { thematic areas including natural resource }\end{array}$ \\
\hline
\end{tabular}




\begin{tabular}{|c|c|c|c|c|}
\hline & & & & $\begin{array}{l}\text { management, capacity building, long-term } \\
\text { ecological monitoring etc. }\end{array}$ \\
\hline Indonesia & Basic & $\begin{array}{l}\text { Terrestrial } \\
\text { forests or } \\
\text { woodlands }\end{array}$ & Planned & Social forestry \\
\hline Jamaica & Basic & $\begin{array}{l}\text { None } \\
\text { (urban) }\end{array}$ & Planned & $\begin{array}{l}\text { The country has also prepared, in } \\
\text { collaboration with other regional } \\
\text { governments and the UNEP, a proposal to } \\
\text { support the implementation of an Urban } \\
\text { Ecosystem-Based Adaptation project in the } \\
\text { capital city of Kingston. This Project will } \\
\text { increase the resilience of Kingston using } \\
\text { ecosystem based approaches. }\end{array}$ \\
\hline \multirow[b]{2}{*}{ Jordan } & \multirow[b]{2}{*}{ Robust } & \multirow[b]{2}{*}{ Agroforestry } & \multirow[b]{2}{*}{ Planned } & $\begin{array}{l}\text { Supporting environment friendly } \\
\text { agriculture and permaculture designs as } \\
\text { well as conservation and sustainable } \\
\text { utilization of plant and animals genetic } \\
\text { resources for food and agriculture that are } \\
\text { climate resilient and adaptive to climate } \\
\text { change especially landraces to improve } \\
\text { rural sector adaptive capacity to changing } \\
\text { environment to enhance food security. }\end{array}$ \\
\hline & & & & $\begin{array}{l}\text { For rain-fed areas: adaptation measures } \\
\text { include, but not limited to, improving soil } \\
\text { water storage to maximize plant water } \\
\text { availability by maximizing infiltration of } \\
\text { rainfall; application of conservation } \\
\text { agriculture, which involves minimum soil } \\
\text { disturbance and encompasses land } \\
\text { preparation techniques that improve soil } \\
\text { fertility; managing crop residue and tillage } \\
\text { and conserving soil and water. }\end{array}$ \\
\hline Jordan & Basic & General & Planned & $\begin{array}{l}\text { Establishing, in partnership with RSCN, a } \\
\text { specialized unit that is responsible for } \\
\text { implementing the adaptation strategies, } \\
\text { liaising with different national } \\
\text { stakeholders and formulating a range of } \\
\text { ecosystem adaptation projects within } \\
\text { Jordan (time frame : by 2025); }\end{array}$ \\
\hline
\end{tabular}




\begin{tabular}{|c|c|c|c|c|}
\hline & & & & $\begin{array}{l}\text { Undertaking more research on vulnerable } \\
\text { ecosystems and communities and } \\
\text { appropriate adaptation priorities, in } \\
\text { addition to identifying indicator species } \\
\text { and carry out monitoring programs on } \\
\text { climate change impact on key species. } \\
\text { (time frame : by 2030); }\end{array}$ \\
\hline & & & & $\begin{array}{l}\text { Enhancing the resilience of local } \\
\text { communities impacted by climate change } \\
\text { in areas within and surrounding PAs } \\
\text { (including community-based pilot } \\
\text { adaptation projects) (time frame: by 2030). }\end{array}$ \\
\hline \multirow{4}{*}{ Lao PDR } & \multirow{4}{*}{ Basic } & \multirow{4}{*}{$\begin{array}{l}\text { Agroforestry, } \\
\text { River } \\
\text { catchments }\end{array}$} & \multirow{4}{*}{ Planned } & $\begin{array}{l}\text { Promote integrated actions on watersheds, } \\
\text { reservoir management, water storage for } \\
\text { agro-forestry, wildlife management, } \\
\text { fisheries and tree varieties, prevention of } \\
\text { drought }\end{array}$ \\
\hline & & & & $\begin{array}{l}\text { Increase awareness and technical capacity } \\
\text { of village forest volunteers on climate } \\
\text { resilient natural forest management, agro- } \\
\text { forestry and plantation technologies }\end{array}$ \\
\hline & & & & $\begin{array}{l}\text { Promote and enhance development of } \\
\text { appropriate technologies to cope with } \\
\text { climate change. This may include the } \\
\text { conservation of agricultural soil... and } \\
\text { maximising the use of indigenous climate } \\
\text { resilient knowledge. }\end{array}$ \\
\hline & & & & $\begin{array}{l}\text { Study and promote the conservation of } \\
\text { wetlands as part of a climate resilient } \\
\text { ecosystem-based approach. }\end{array}$ \\
\hline \multirow{3}{*}{ Lao PDR } & \multirow{3}{*}{ Robust } & \multirow{3}{*}{$\begin{array}{l}\text { Terrestrial } \\
\text { forests or } \\
\text { woodlands, } \\
\text { River } \\
\text { catchments }\end{array}$} & \multirow{3}{*}{ Planned } & $\begin{array}{l}\text { Promote Climate Resilience in Forestry } \\
\text { Production and Forest Ecosystems }\end{array}$ \\
\hline & & & & $\begin{array}{l}\text { Develop and enforce appropriate laws, } \\
\text { regulations and implement guidelines for } \\
\text { sustainable forest management }\end{array}$ \\
\hline & & & & $\begin{array}{l}\text { Strengthen capacity in integrated land use } \\
\text { planning, watershed forest management, } \\
\text { reduction of slash and burn practices to } \\
\text { increase the resilience of forests to cope } \\
\text { with climate change }\end{array}$ \\
\hline
\end{tabular}




\begin{tabular}{|c|c|c|c|c|}
\hline & & & & $\begin{array}{l}\text { Forest surveys and allocation for } \\
\text { sustainable management and rural } \\
\text { development }\end{array}$ \\
\hline & & & & $\begin{array}{l}\text { Strengthen the capacity of technical staff } \\
\text { and village forest volunteers to enable } \\
\text { optimal planting, managing and utilising } \\
\text { community forests in response to climate } \\
\text { change }\end{array}$ \\
\hline & & & & $\begin{array}{l}\text { Promote forest seed and seedling } \\
\text { production for reforestation and forest } \\
\text { restoration }\end{array}$ \\
\hline & & & & $\begin{array}{l}\text { Research and select forest species which } \\
\text { are resilient to pests, diseases, drought, } \\
\text { and soil erosion. }\end{array}$ \\
\hline & & & & $\begin{array}{l}\text { Promote Technical Capacity in the } \\
\text { Forestry Sector for Managing Forests for } \\
\text { Climate Change Adaptation }\end{array}$ \\
\hline & & & & $\begin{array}{l}\text { Increase awareness and technical capacity } \\
\text { of village forest volunteers on climate } \\
\text { resilient natural forest management, agro- } \\
\text { forestry and plantation technologies }\end{array}$ \\
\hline Lesotho & Robust & $\begin{array}{l}\text { Terrestrial } \\
\text { forests or } \\
\text { woodlands }\end{array}$ & Current & $\begin{array}{l}\text { Pursuant to this policy, the Forestry Act of } \\
1998 \text { was promulgated and a new National } \\
\text { Forest Policy was launched in } 2008 \text { to } \\
\text { pursue sustainable forest management; } \\
\text { poverty reduction strategy through social } \\
\text { and economic dimensions of forestry } \\
\text { development and enhancing people's } \\
\text { participation in the on-going Land } \\
\text { Rehabilitation Program of the Government } \\
\text { of Lesotho. }\end{array}$ \\
\hline Lesotho & Basic & Agroforestry & Current & $\begin{array}{l}\text { Conservation agriculture: advocacy, } \\
\text { extension / training, research integration } \\
\text { into formal curricula }\end{array}$ \\
\hline Lesotho & Basic & General & Current & $\begin{array}{l}\text { Eco-system based climate change } \\
\text { adaptation in southern Lesotho }\end{array}$ \\
\hline Liberia & Basic & Agroforestry & Planned & $\begin{array}{l}\text { Develop climate resilient } \\
\text { crop/agroforestry diversification and } \\
\text { livestock production systems }\end{array}$ \\
\hline
\end{tabular}




\begin{tabular}{|c|c|c|c|c|}
\hline Liberia & Basic & $\begin{array}{l}\text { Terrestrial } \\
\text { forests or } \\
\text { woodlands }\end{array}$ & Planned & $\begin{array}{l}\text { Forestry: Increase awareness and } \\
\text { strengthen participation of local dwellers } \\
\text { in forest conservation. }\end{array}$ \\
\hline Madagascar & Basic & Agroforestry & Current & $\begin{array}{l}\text { Development of Resilient Agriculture } \\
\text { Integrated Model pilot } \\
\text { projects/programmes (combination of } \\
\text { watershed management, selected/adapted } \\
\text { varieties, locally-produced compost, } \\
\text { rehabilitation of hydro-agricultural } \\
\text { infrastructures, input access facilitation } \\
\text { system, conservation agriculture, and } \\
\text { agroforestry) or "climate-smart } \\
\text { agriculture"; }\end{array}$ \\
\hline Madagascar & Basic & $\begin{array}{l}\text { Coastal and } \\
\text { marine } \\
\text { habitats, } \\
\text { Grasslands } \\
\text { and } \\
\text { rangelands }\end{array}$ & Planned & $\begin{array}{l}\text { Implementation of ecosystem-based } \\
\text { adaptation to cope with sand-hill } \\
\text { progression (multiple causes but } \\
\text { phenomena aggravated by climate change) } \\
\text { by leveraging research findings and best } \\
\text { practices; }\end{array}$ \\
\hline Malawi & Basic & Agroforestry & Planned & $\begin{array}{l}\text { Implement conservation agriculture and } \\
\text { agroforestry practices }\end{array}$ \\
\hline Malawi & Basic & $\begin{array}{l}\text { River } \\
\text { catchments }\end{array}$ & Planned & $\begin{array}{l}\text { Adopt eco-system services approach in the } \\
\text { management of fisheries resources }\end{array}$ \\
\hline Malawi & Robust & $\begin{array}{l}\text { Terrestrial } \\
\text { forests or } \\
\text { woodlands }\end{array}$ & Planned & $\begin{array}{l}\text { Overtime, communities may adapt by } \\
\text { planting tree species that are drought } \\
\text { tolerant and fast growing such as } \\
\text { bamboos. This would reduce pressure on } \\
\text { standing forests since communities would } \\
\text { be harvesting wood for fuel from their } \\
\text { own woodlots. Some mitigation } \\
\text { interventions in the forestry sector also } \\
\text { have adaptation co-benefits elements. For } \\
\text { example, forest regeneration could spur } \\
\text { bee-keeping and indigenous mushroom } \\
\text { harvesting thereby taking people-off from } \\
\text { forest extractive activities. }\end{array}$ \\
\hline Maldives & Basic & $\begin{array}{l}\text { Coastal and } \\
\text { marine } \\
\text { habitats }\end{array}$ & Planned & $\begin{array}{l}\text { Coral reefs conservation through } \\
\text { ecosystem approach as an adaptation } \\
\text { measure to increase the resilience of the } \\
\text { coral reef ecosystem. }\end{array}$ \\
\hline
\end{tabular}




\begin{tabular}{|c|c|c|c|c|}
\hline Mali & Basic & Agroforestry & Planned & $\begin{array}{l}\text { Reforestation and planning of fruit trees to } \\
\text { reconstruct the vegetation cover and } \\
\text { protect agricultural areas from water and } \\
\text { wind erosion }\end{array}$ \\
\hline Mali & & $\begin{array}{l}\text { Terrestrial } \\
\text { forests or } \\
\text { woodlands }\end{array}$ & Planned & $\begin{array}{l}\text { Of forest management for the restoration } \\
\text { of degraded ecosystems to reforest } 325,000 \\
\text { hectares promote assisted natural } \\
\text { regeneration and the fight against silting } \\
\text { and strengthen the protection of protected } \\
\text { areas on } 9 \text { million hectares }\end{array}$ \\
\hline \multirow[b]{2}{*}{ Mexico } & \multirow[b]{2}{*}{ Basic } & \multirow[b]{2}{*}{$\begin{array}{l}\text { River } \\
\text { catchments }\end{array}$} & \multirow[b]{2}{*}{ Planned } & $\begin{array}{l}\text { Guarantee food security and water access } \\
\text { in light of growing climate threats through } \\
\text { integral watershed management, } \\
\text { biodiversity and land conservation }\end{array}$ \\
\hline & & & & $\begin{array}{l}\text { Reforest high, medium and low } \\
\text { watersheds with special attention to } \\
\text { riparian zones and taking into account } \\
\text { native species in the area (in the context of } \\
\text { EbA actions) }\end{array}$ \\
\hline Mexico & Robust & General & Planned & $\begin{array}{l}\text { Conserve and restore ecosystems in order } \\
\text { to increase ecological connectivity of all } \\
\text { Natural Protected Areas and other } \\
\text { conservation schemes, through biological } \\
\text { corridors and sustainable productive } \\
\text { activities. This approach will take into } \\
\text { account the equitable participation of the } \\
\text { population and will have a territorial } \\
\text { approach. }\end{array}$ \\
\hline \multirow[b]{3}{*}{ Moldova } & \multirow[b]{3}{*}{ Robust } & \multirow[b]{3}{*}{$\begin{array}{l}\text { Terrestrial } \\
\text { forests or } \\
\text { woodlands }\end{array}$} & \multirow[b]{3}{*}{ Planned } & $\begin{array}{l}\text { Action 3.4: Risk Management and Climate } \\
\text { Change Adaptation in the Forestry Sector }\end{array}$ \\
\hline & & & & $\begin{array}{l}\text { The following climate change adaptation } \\
\text { measures could be implemented in the } \\
\text { Forestry Sector: }\end{array}$ \\
\hline & & & & $\begin{array}{l}\text { a) revision and development of new } \\
\text { important components of the forestry } \\
\text { regulatory basis, as integral parts of the } \\
\text { forestry regime, focusing on: maintenance } \\
\text { and conservation of forestry stations; } \\
\text { conservation of forestry genetic resources; } \\
\text { ecological reconstruction of forests; }\end{array}$ \\
\hline
\end{tabular}




\begin{tabular}{|c|c|c|c|c|}
\hline & & & & $\begin{array}{l}\text { certification of forests, forest products and } \\
\text { forest management systems; }\end{array}$ \\
\hline & & & & $\begin{array}{l}\text { c) development and approval of the } \\
\text { regulation on implementation and } \\
\text { assuring functionality of the principles of } \\
\text { participatory management of public forest } \\
\text { resources; }\end{array}$ \\
\hline & & & & $\begin{array}{l}\text { d) increasing the forest cover, including in } \\
\text { the climate change context mitigation and } \\
\text { biodiversity conservation; }\end{array}$ \\
\hline & & & & $\begin{array}{l}\text { e) development and implementation of } \\
\text { projects aimed at planting protection } \\
\text { forestry strips (buffer zones) for } \\
\text { agricultural lands protection, anti- } \\
\text { erosional purpose, and for waters } \\
\text { protection; }\end{array}$ \\
\hline & & & & $\begin{array}{l}\text { f) establishment of plantation forests to } \\
\text { meet the needs of population in fuel wood } \\
\text { for heating, cooking etc.; }\end{array}$ \\
\hline & & & & $\begin{array}{l}\text { g) develop methodologies/technologies to } \\
\text { assure forest ecosystems adaptability to } \\
\text { climate change. }\end{array}$ \\
\hline & & & & $\begin{array}{l}\text { To build capacity of community forestry } \\
\text { groups to conduct modern technologies } \\
\text { for forest seedlings and tree plantations }\end{array}$ \\
\hline Mongolia & Basic & $\begin{array}{l}\text { Terrestrial } \\
\text { forests or }\end{array}$ & Current & $\begin{array}{l}\text { To make forests resilient to climate change } \\
\text { by improving their productivity and } \\
\text { changing their composition and structure }\end{array}$ \\
\hline & & & & $\begin{array}{l}\text { To train human resources for forest } \\
\text { management practices }\end{array}$ \\
\hline & & & & $\begin{array}{l}\text { Forest area will be increased to } 9 \% \text { by } 2030 \\
\text { through reforestation activities }\end{array}$ \\
\hline Myanmar & Basic & $\begin{array}{l}\text { River } \\
\text { catchmentss }\end{array}$ & Planned & $\begin{array}{l}\text { The Forest Department within MOECAF is } \\
\text { focusing on the sustainability of } \\
\text { watersheds and to prevent sedimentation } \\
\text { inside dams and reservoirs by drafting a } \\
\text { National Watershed Management Policy } \\
\text { (2014) and formulating Action Plans for } \\
\text { establishing watershed plantations in } \\
\text { watershed areas of major dams, reservoirs }\end{array}$ \\
\hline
\end{tabular}




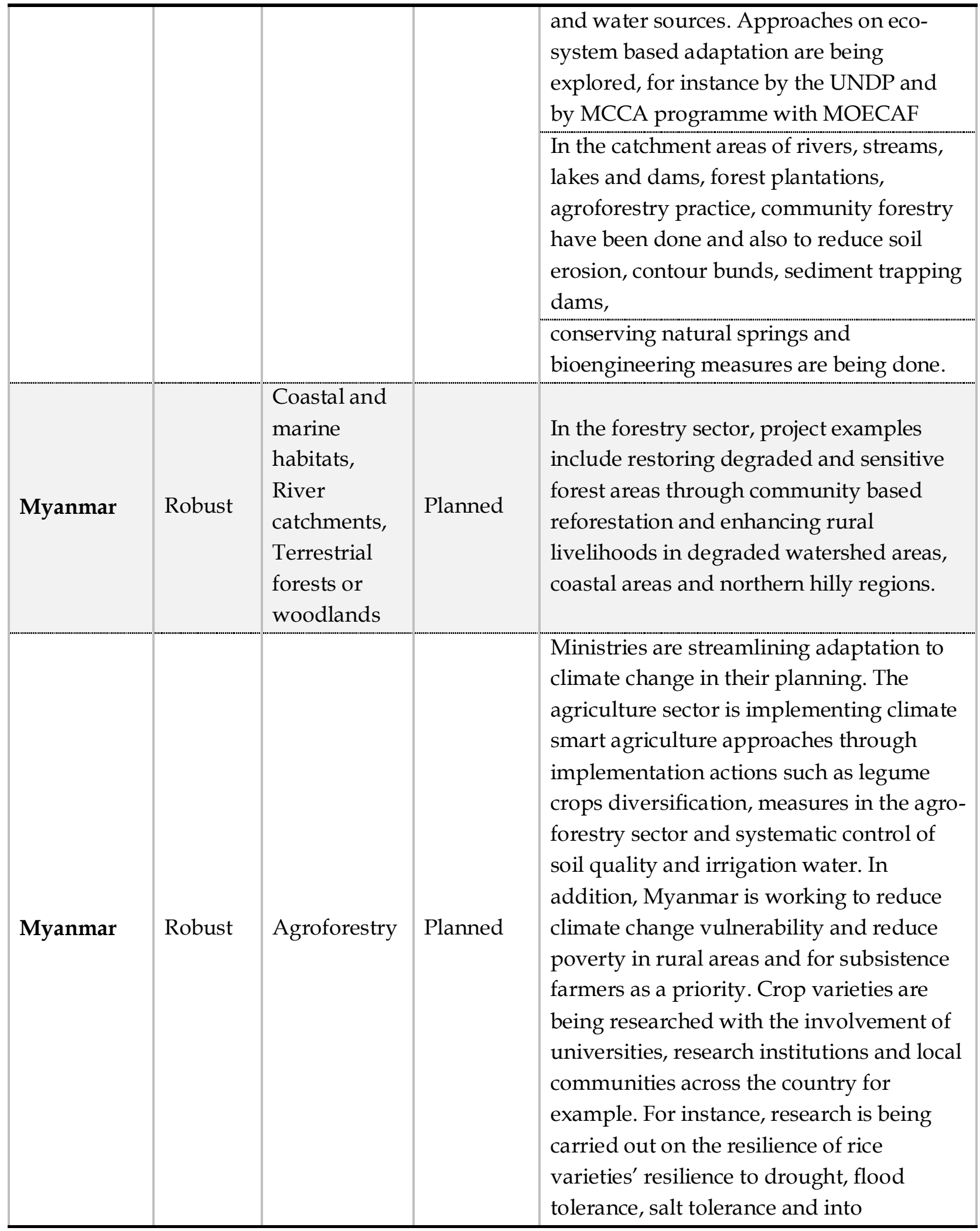




\begin{tabular}{|c|c|c|c|c|}
\hline & & & & $\begin{array}{l}\text { alternative varieties that are resistant to } \\
\text { pests and disease. }\end{array}$ \\
\hline Myanmar & Basic & $\begin{array}{l}\text { None } \\
\text { (urban) }\end{array}$ & Planned & $\begin{array}{l}\text { Eco-system based approaches to } \\
\text { adaptation at township level will be tested } \\
\text { during the course of 2016-18, including a } \\
\text { vulnerability analysis of the following } \\
\text { elements: urban planning, infrastructure } \\
\text { development, environmental risk and } \\
\text { livelihood patterns. This will be followed } \\
\text { by implementation of solutions to } \\
\text { identified issues. }\end{array}$ \\
\hline Namibia & Basic & $\begin{array}{l}\text { Terrestrial } \\
\text { forests or } \\
\text { woodlands }\end{array}$ & Current & Community forest management; \\
\hline Namibia & Basic & Agroforestry & Current & $\begin{array}{l}\text { Promotion of Climate Smart Agriculture } \\
\text { and Conservation Agriculture; }\end{array}$ \\
\hline Nepal & Robust & $\begin{array}{l}\text { Terrestrial } \\
\text { forests or } \\
\text { woodlands }\end{array}$ & Current & $\begin{array}{l}\text { More than } 25,000 \text { community-based forest } \\
\text { management groups across the country } \\
\text { are directly engaged in managing about } \\
30 \% \text { of the country's total forest area. } \\
\text { These community-based organizations are } \\
\text { not only contributing to sequestering } \\
\text { carbon dioxide by sustainable } \\
\text { management of forest resources but also } \\
\text { playing effective roles in designing and } \\
\text { implementing Community Adaptation } \\
\text { Plans of Action (CAPAs) based on forests } \\
\text { and non-forests benefits. }\end{array}$ \\
\hline \multirow{7}{*}{ Niger } & \multirow{7}{*}{ Basic } & \multirow{7}{*}{$\begin{array}{l}\text { Terrestrial } \\
\text { forests or } \\
\text { woodlands }\end{array}$} & \multirow{7}{*}{ Planned } & Assisted natural regeneration: $1,100,000$ ha \\
\hline & & & & Fixation of dunes: 550,000 ha \\
\hline & & & & $\begin{array}{l}\text { Management of natural forests: } 2,220,000 \\
\text { ha }\end{array}$ \\
\hline & & & & Hedgerows: $145,000 \mathrm{~km}$ \\
\hline & & & & Planting of multiuse species: 750,000 ha \\
\hline & & & & Planting of Moringa oleifera: 125,000 ha \\
\hline & & & & Seeding of roadways: 304,500 ha \\
\hline
\end{tabular}




\begin{tabular}{|c|c|c|c|c|}
\hline \multirow{5}{*}{ Nigeria } & \multirow{5}{*}{ Basic } & \multirow{5}{*}{$\begin{array}{l}\text { Terrestrial } \\
\text { forests or } \\
\text { woodlands }\end{array}$} & \multirow{5}{*}{ Planned } & $\begin{array}{l}\text { 1.) Strengthen the implementation of the } \\
\text { national Community-Based Forest } \\
\text { Resources Management Program. }\end{array}$ \\
\hline & & & & $\begin{array}{l}\text { 2.) Support review and implementation } \\
\text { of the National Forest Policy }\end{array}$ \\
\hline & & & & $\begin{array}{l}\text { 3.) Develop and maintain a frequent } \\
\text { forest inventory system to facilitate } \\
\text { monitoring of forest status; and initiate a } \\
\text { research programme on a range of climate } \\
\text { change-related topics, including long term } \\
\text { impacts of climatic shifts on closed forests }\end{array}$ \\
\hline & & & & $\begin{array}{l}\text { 4.) Provide extension services to CSOs, } \\
\text { communities and the private sector to help } \\
\text { establish and restore community and } \\
\text { private natural forests, plantations and } \\
\text { nurseries }\end{array}$ \\
\hline & & & & $\begin{array}{l}\text { 5.) Improve management of forest } \\
\text { reserves and enforce low impact logging } \\
\text { practice }\end{array}$ \\
\hline $\begin{array}{l}\text { North } \\
\text { Korea }\end{array}$ & Basic & $\begin{array}{l}\text { Terrestrial } \\
\text { forests or } \\
\text { woodlands }\end{array}$ & Planned & $\begin{array}{l}\text { Recovery of degraded forest and firewood } \\
\text { forest managment in community areas }\end{array}$ \\
\hline Peru & Basic & $\begin{array}{l}\text { Montane } \\
\text { habitats }\end{array}$ & Current & $\begin{array}{l}\text { Note only mentioned in footnote: The } \\
\text { Adaptation project based on Mountain } \\
\text { Ecosystems "EbA Mountains" }\end{array}$ \\
\hline & & & & $\begin{array}{l}\text { 3.1Promote afforestation/ reforestation of } \\
\text { designated areas through enhanced } \\
\text { germplasm and technical practices in } \\
\text { planting and post-planting processes; }\end{array}$ \\
\hline Rwanda & Basic & $\begin{array}{l}\text { Terrestrial } \\
\text { forests or } \\
\text { woodlands }\end{array}$ & Current & $\begin{array}{l}\text { The Rwandan forestry sector provides the } \\
\text { main part of the primary energy needs } \\
\text { ( } 97 \% \text { of cooking energy) to the population. } \\
\text { Since } 2002, \text { there have been consistent gap } \\
\text { in wood products supply and demand } \\
\text { with deficits reaching } 12 \text { million cubic } \\
\text { meters in } 2009 \text {. This deficit shows how the } \\
\text { forest sector is and likely to remain under } \\
\text { pressure. In order to deal with this main } \\
\text { issue, Rwanda intends to improve the } \\
\text { management of its forest resources by }\end{array}$ \\
\hline
\end{tabular}




\begin{tabular}{|c|c|c|c|c|}
\hline & & & & $\begin{array}{l}\text { increasing efforts in using quality } \\
\text { germplasm, planting trees at the right time } \\
\text { (rain season) and improving post-planting } \\
\text { care. Furthermore, the country intends to } \\
\text { use mixed-species approaches which } \\
\text { contribute greatly to the achievement of } \\
\text { both mitigation objectives and adaptation } \\
\text { benefits of ecosystem resilience and } \\
\text { biodiversity. Through this strategic action, } \\
\text { the country's target is to achieve an overall } \\
30 \% \text { sustained forest cover of the total } \\
\text { national land surface by } 2030 \text { from } 28.8 \% \\
\text { in } 2013 \text {. }\end{array}$ \\
\hline & & & & $\begin{array}{l}\text { 3.2 Employ Improved Forest Management } \\
\text { for degraded forest resources; Land } \\
\text { scarcity is a primary constraint to the } \\
\text { expansion of Rwanda's forest resources. } \\
\text { Rwanda should maximize the productivity } \\
\text { of its many degraded forest plantations } \\
\text { which present an opportunity to increase } \\
\text { biomass supply without converting } \\
\text { additional land. By 2030, Rwanda will } \\
\text { implement public private partnerships to } \\
\text { sustainably managing all forestry } \\
\text { plantations through multiyear contracts } \\
\text { with forests operators (in cooperatives) } \\
\text { who will plant and maintain young } \\
\text { plantations until they reach their } \\
\text { commercial size. }\end{array}$ \\
\hline \multirow[b]{2}{*}{ Rwanda } & \multirow[b]{2}{*}{ Robust } & \multirow[b]{2}{*}{ Agroforestry } & \multirow[b]{2}{*}{ Current } & $\begin{array}{l}\text { 1.1 Mainstreaming agro ecology } \\
\text { techniques using spatial plant stacking as } \\
\text { in agro forestry, kitchen gardens, nutrient } \\
\text { recycling, and water conservation to } \\
\text { maximise sustainable food production; }\end{array}$ \\
\hline & & & & $\begin{array}{l}\text { Rwanda intends to mainstream agro } \\
\text { ecology technologies in its current } \\
\text { agriculture intensification programme and } \\
\text { other natural resource-based livelihood } \\
\text { programmes. } 100 \% \text { of the households } \\
\text { involved in agriculture production will be }\end{array}$ \\
\hline
\end{tabular}




\begin{tabular}{|c|c|c|c|c|}
\hline & & & & $\begin{array}{l}\text { implementing agro forestry sustainable } \\
\text { food production by } 2030 \text {. }\end{array}$ \\
\hline & & & & $\begin{array}{l}\text { 1.5 Soil conservation and land husbandry - } \\
90 \% \text { of Rwanda's crop land is on slopes } \\
\text { ranging from } 5 \text { to } 50 \% \text { which makes it } \\
\text { vulnerable to climate change impacts like } \\
\text { soil erosion leading to permanent fertility } \\
\text { loss. Rwanda intends to expand its soil } \\
\text { conservation and land husbandry } \\
\text { programmes through: Installation of land } \\
\text { protection structures like radical and } \\
\text { progressive terraces where these } \\
\text { structures will be installed on } 100 \% \text { of the } \\
\text { relevant area by } 2030 \text {; Development and } \\
\text { implementation of an intensive } \\
\text { agroforestry programme with a target of } \\
\text { covering } 100 \% \text { of arable land by } 2030 \text {. }\end{array}$ \\
\hline $\begin{array}{l}\text { Sao Tome } \\
\text { and } \\
\text { Principe }\end{array}$ & Basic & Agroforestry & Planned & $\begin{array}{l}\text { Depending on the future availability of } \\
\text { financial, technological and capacity- } \\
\text { building support provided by the } \\
\text { international community, the country } \\
\text { plans in short and medium terms to } \\
\text { implement the following actions: III. } \\
\text { Develop a national program for } \\
\text { sustainable management of the forest and } \\
\text { agro forestry ecosystems by 2025; }\end{array}$ \\
\hline $\begin{array}{l}\text { Saudi } \\
\text { Arabia }\end{array}$ & Basic & $\begin{array}{l}\text { Coastal and } \\
\text { marine } \\
\text { habitats }\end{array}$ & Planned & $\begin{array}{l}\text { Marine Protection: Implement coastal } \\
\text { management strategies that are designed } \\
\text { to reduce coastal erosion, increase the } \\
\text { sinks for blue carbon, maintain related } \\
\text { ecosystems and address the threats that } \\
\text { climate change poses for marine } \\
\text { livelihoods. Support the planting of } \\
\text { mangrove seedlings along its coasts. In } \\
\text { addition, strengthen and enhance the coral } \\
\text { reef restoration program throughout the } \\
\text { northwestern Arabian Gulf. }\end{array}$ \\
\hline \multirow[b]{2}{*}{ Senegal } & \multirow[b]{2}{*}{ Basic } & \multirow[b]{2}{*}{ Agroforestry } & \multirow[b]{2}{*}{ Planned } & Sustainable Land Management \\
\hline & & & & $\begin{array}{l}\text { Application of good practices in } \\
\text { Agroforestry, Natural Assisted }\end{array}$ \\
\hline
\end{tabular}




\begin{tabular}{|c|c|c|c|c|}
\hline & & & & $\begin{array}{l}\text { Regeneration (NAS) and the use of organic } \\
\text { manure on half of the area sown by } 2035\end{array}$ \\
\hline & & & & $\begin{array}{l}\text { Agroforestry: Combination of trees, } \\
\text { conventional crops and / or animals in the } \\
\text { form of an arrangement }\end{array}$ \\
\hline Seychelles & Basic & $\begin{array}{l}\text { Coastal and } \\
\text { marine } \\
\text { habitats, } \\
\text { River } \\
\text { catchments }\end{array}$ & Current & $\begin{array}{l}\text { Seychelles is currently implementing three } \\
\text { ecosystem-based adaptation projects } \\
\text { funded by the GEF Climate Change } \\
\text { Adaptation Fund, UNEP and the } \\
\text { Government of China. The projects focus } \\
\text { on management of coastal ecosystems, } \\
\text { protection of mangroves, and sustainable } \\
\text { watershed management collectively. }\end{array}$ \\
\hline \multirow{3}{*}{ Somalia } & \multirow{3}{*}{ Robust } & \multirow{3}{*}{$\begin{array}{l}\text { Agroforestry, } \\
\text { Grasslands } \\
\text { and } \\
\text { rangelands, } \\
\text { Terrestrial } \\
\text { forests or } \\
\text { woodlands, } \\
\text { River } \\
\text { catchments }\end{array}$} & \multirow{3}{*}{ Planned } & $\begin{array}{l}\text { Introduce integrated land use } \\
\text { management (rangeland, reforestation, } \\
\text { agro-forestry and watershed management) } \\
\text { planning principles to district and } \\
\text { community stakeholders. }\end{array}$ \\
\hline & & & & $\begin{array}{l}\text { The objective of this proposal is to initiate } \\
\text { the domestication of economically } \\
\text { important indigenous species and to } \\
\text { introduce, test and disseminate equally } \\
\text { important species from areas with similar } \\
\text { agro-ecological conditions. This initiative } \\
\text { would enable the farming communities in } \\
\text { different ecological zones to cultivate, use } \\
\text { and market the products of these species. }\end{array}$ \\
\hline & & & & $\begin{array}{l}\text { In order to assure success and } \\
\text { sustainability, the local farmers and } \\
\text { communities will be involved in the } \\
\text { planning and the selection of priority } \\
\text { species in their area. }\end{array}$ \\
\hline Somalia & Robust & $\begin{array}{l}\text { Coastal and } \\
\text { marine } \\
\text { habitats }\end{array}$ & Planned & $\begin{array}{l}\text { In order to restore the Marine and Coastal } \\
\text { Environment of Somalia, including the } \\
\text { replanting of mangroves, protecting } \\
\text { marine species, preventing and halting } \\
\text { coastal mining stones for urban } \\
\text { construction through environmental } \\
\text { policy, legal and regulatory actions, mass } \\
\text { media awareness, arranging workshops, }\end{array}$ \\
\hline
\end{tabular}




\begin{tabular}{|c|c|c|c|c|}
\hline & & & & $\begin{array}{l}\text { seminars and meetings to build up the } \\
\text { capacity of the coastal communities to } \\
\text { contribute to sustainable development of } \\
\text { coastal and marine resources and to } \\
\text { through remedial action regain depleted } \\
\text { resources. }\end{array}$ \\
\hline Somalia & Basic & $\begin{array}{l}\text { Terrestrial } \\
\text { forests or } \\
\text { woodlands, } \\
\text { Grasslands } \\
\text { and } \\
\text { rangelands }\end{array}$ & Planned & $\begin{array}{l}\text { Rehabilitation and reinstatement of } \\
\text { degraded ecosystems, in particular } \\
\text { rangeland areas, forests and areas with a } \\
\text { high potential for cultivation, to provide } \\
\text { sustainable grazing, forestry products, and } \\
\text { agriculturally productive zones. }\end{array}$ \\
\hline $\begin{array}{l}\text { South } \\
\text { Sudan }\end{array}$ & Robust & Agroforestry & Planned & $\begin{array}{l}\text { i. Promote agro-forestry practices as a way } \\
\text { of diversifying land production systems } \\
\text { and promoting alternative livelihood } \\
\text { options. }\end{array}$ \\
\hline $\begin{array}{l}\text { South } \\
\text { Sudan }\end{array}$ & Robust & $\begin{array}{l}\text { Terrestrial } \\
\text { forests or } \\
\text { woodlands, } \\
\text { River } \\
\text { catchments }\end{array}$ & Planned & $\begin{array}{l}\text { ii. Promote afforestation of degraded } \\
\text { landscapes/watersheds using multiuse } \\
\text { forest species to increase community } \\
\text { safety-nets and diversify livelihoods. }\end{array}$ \\
\hline Sri Lanka & Basic & Agroforestry & Planned & $\begin{array}{l}\text { Promote traditional methods of } \\
\text { biodiversity conservation for increased } \\
\text { resilience in agro-ecosystems. }\end{array}$ \\
\hline Sri Lanka & Basic & $\begin{array}{l}\text { Coastal and } \\
\text { marine } \\
\text { habitats }\end{array}$ & Planned & $\begin{array}{l}\text { Improve protection and conservation } \\
\text { measures in all drinking water catchment } \\
\text { areas }\end{array}$ \\
\hline $\begin{array}{l}\text { St. Vincent } \\
\text { and the } \\
\text { Grenadines }\end{array}$ & Robust & $\begin{array}{l}\text { Terrestrial } \\
\text { forests or } \\
\text { woodlands }\end{array}$ & Planned & $\begin{array}{l}\text { The implementation of the National Forest } \\
\text { Resources Conservation Plan (1994-2003) } \\
\text { and Integrated Forest Management and } \\
\text { Development Programme to address } \\
\text { issues of rapid deforestation, limited } \\
\text { involvement of communities in forest } \\
\text { resource management, weak institutional } \\
\text { capacity, lack of an approved forestry } \\
\text { policy framework, fragmented } \\
\text { environmental management and limited } \\
\text { awareness of the importance of forests to } \\
\text { national development. }\end{array}$ \\
\hline
\end{tabular}




\begin{tabular}{|c|c|c|c|c|}
\hline & & & & $\begin{array}{l}\text { Enhancing the adaptive capacity of rural } \\
\text { economies and natural resources to } \\
\text { climate change through the management } \\
\text { and protection of land based natural } \\
\text { resources and agricultural production } \\
\text { systems. }\end{array}$ \\
\hline \multirow{3}{*}{ Sudan } & \multirow{3}{*}{ Robust } & \multirow{3}{*}{$\begin{array}{l}\text { Agroforestry, } \\
\text { Terrestrial } \\
\text { forests or } \\
\text { woodlands }\end{array}$} & \multirow{3}{*}{ Planned } & $\begin{array}{l}\text { Introduction of agroforestry in areas } \\
\text { vulnerable to climate change to enhance } \\
\text { agricultural production as well as } \\
\text { empower vulnerable communities through } \\
\text { their involvement in community forests } \\
\text { activities / products }\end{array}$ \\
\hline & & & & $\begin{array}{l}\text { Enhancing the participation of women and } \\
\text { youth in activities related to adaptation } \\
\text { and environmental conservation in order } \\
\text { to empower them and enhance their } \\
\text { adaptive capacity including through } \\
\text { establishment rural development } \\
\text { programme }\end{array}$ \\
\hline & & & & $\begin{array}{l}\text { Planting shelterbelts, introduction of high } \\
\text { economic value trees and rehabilitation of } \\
\text { the Gum Arabic gardens to increase the } \\
\text { resilience of vulnerable communities } \\
\text { through engagement in a range of forestry } \\
\text { activities }\end{array}$ \\
\hline Sudan & Robust & $\begin{array}{l}\text { Grasslands } \\
\text { and } \\
\text { rangelands }\end{array}$ & Planned & $\begin{array}{l}\text { Establishment of range's } \\
\text { enclosures/ranches to increase resilience } \\
\text { of vulnerable communities }\end{array}$ \\
\hline Suriname & Basic & $\begin{array}{l}\text { Coastal and } \\
\text { marine } \\
\text { habitats }\end{array}$ & Planned & $\begin{array}{l}\text { These assessments also supported the } \\
\text { identification of critical adaptation } \\
\text { measures of which some are under } \\
\text { implementation such as the drafted law } \\
\text { for protecting the unprotected parts of the } \\
\text { mangrove forests along the coast. The } \\
\text { reasons for this measure are to increase } \\
\text { natural protection of the vulnerable } \\
\text { coastline; protect the mangrove } \\
\text { ecosystems on the coast; sequester carbon } \\
\text { and reduce GHG emissions caused by } \\
\text { uprooting of plants during coastal erosion; }\end{array}$ \\
\hline
\end{tabular}




\begin{tabular}{|c|c|c|c|c|}
\hline & & & & $\begin{array}{l}\text { to promote natural mangrove regeneration } \\
\text { leading to increased fish production and } \\
\text { reduced poverty levels. }\end{array}$ \\
\hline Swaziland & Basic & Agroforestry & Planned & $\begin{array}{l}\text { The possible actions that have been } \\
\text { identified to achieve these contributions } \\
\text { include: agro-forestry; ecological pest } \\
\text { management; flood mapping; grazing land } \\
\text { management; degraded land } \\
\text { rehabilitation; fire management; and } \\
\text { erosion control through terracing. }\end{array}$ \\
\hline \multirow{3}{*}{ Thailand } & \multirow{3}{*}{ Robust } & \multirow{3}{*}{$\begin{array}{l}\text { Coastal and } \\
\text { marine } \\
\text { habitats, } \\
\text { River } \\
\text { catchments, } \\
\text { Terrestrial } \\
\text { forests or } \\
\text { woodlands }\end{array}$} & \multirow{3}{*}{ Planned } & $\begin{array}{l}\text { Sustainable management of community } \\
\text { forests to promote food security at the } \\
\text { community level }\end{array}$ \\
\hline & & & & $\begin{array}{l}\text { Increase national forest cover to } 40 \% \\
\text { through local community participation, } \\
\text { including in particular headwater and } \\
\text { mangrove forests to enhance adaptive } \\
\text { capacities of related ecosystem }\end{array}$ \\
\hline & & & & $\begin{array}{l}\text { Develop participatory, integrated marine } \\
\text { conservation and coastal rehabilitation } \\
\text { plan to protect marine ecosystem and } \\
\text { enhance climate proofing infrastructure to } \\
\text { strengthen coastal protection against } \\
\text { erosion }\end{array}$ \\
\hline Timor-Leste & Basic & Agroforestry & Planned & $\begin{array}{l}\text { Develop integrated agroforestry and } \\
\text { watershed management including climate } \\
\text { change dimensions }\end{array}$ \\
\hline Timor-Leste & Basic & $\begin{array}{l}\text { Terrestrial } \\
\text { forests or } \\
\text { woodlands }\end{array}$ & Planned & $\begin{array}{l}\text { Reforestation of degraded land to prevent } \\
\text { landslides and provide a sustainable fuel } \\
\text { wood source in priority areas with high } \\
\text { vulnerability to climate-related risks }\end{array}$ \\
\hline Togo & Basic & $\begin{array}{l}\text { Terrestrial } \\
\text { forests or } \\
\text { woodlands }\end{array}$ & Current & $\begin{array}{l}\text { Project to strengthen the role of } \\
\text { conservation of the national system of } \\
\text { protected areas in Togo; - Support for the } \\
\text { development and community-based } \\
\text { restoration of gallery forests and forests of } \\
\text { village lands in the plateau region; } \\
\text { Support for the formulation and } \\
\text { implementation of Togo's National } \\
\text { Reforestation Programme (PRO); Support }\end{array}$ \\
\hline
\end{tabular}




\begin{tabular}{|c|c|c|c|c|}
\hline & & & & $\begin{array}{l}\text { for reducing emissions linked to } \\
\text { deforestation and the degradation of } \\
\text { forests (REDD+- readiness) and the } \\
\text { rehabilitation of forests in Togo } \\
\text { (ProREDD+); PRODRA, the Programme } \\
\text { for Rural Development and Agriculture; } \\
\text { and the Project for integrated disaster and } \\
\text { land management (PGICT). }\end{array}$ \\
\hline \multirow[t]{2}{*}{ Tonga } & \multirow[t]{2}{*}{ Basic } & \multirow[t]{2}{*}{ Agroforestry } & \multirow[t]{2}{*}{ Planned } & $\begin{array}{l}\text { 7. Encouraging tax allotment holders to } \\
\text { plant and manage trees on their } \\
\text { properties. }\end{array}$ \\
\hline & & & & $\begin{array}{l}\text { 5. Promoting integrated agroforestry in } \\
\text { areas earmarked for agriculture; }\end{array}$ \\
\hline Uganda & Basic & Agroforestry & Planned & Encouraging agro-forestry \\
\hline $\begin{array}{l}\text { United } \\
\text { Arab } \\
\text { Emirates }\end{array}$ & Basic & $\begin{array}{l}\text { Coastal and } \\
\text { marine } \\
\text { habitats }\end{array}$ & Current & $\begin{array}{l}\text { The UAE is also undergoing significant } \\
\text { restoration and plantation efforts of both } \\
\text { mangroves and sea-grass, supporting } \\
\text { ecosystem-based adaptation as well. }\end{array}$ \\
\hline $\begin{array}{l}\text { United } \\
\text { republic of } \\
\text { Tanzania }\end{array}$ & Basic & $\begin{array}{l}\text { Grasslands } \\
\text { and } \\
\text { rangelands }\end{array}$ & Planned & $\begin{array}{l}\text { Promoting climate change resilient } \\
\text { traditional and modern knowledge on } \\
\text { sustainable pasture and range } \\
\text { management systems. }\end{array}$ \\
\hline \multirow{3}{*}{$\begin{array}{l}\text { United } \\
\text { republic of } \\
\text { Tanzania }\end{array}$} & \multirow{3}{*}{ Basic } & \multirow{3}{*}{$\begin{array}{l}\text { Terrestrial } \\
\text { forests or } \\
\text { woodlands }\end{array}$} & \multirow{3}{*}{ Planned } & $\begin{array}{l}\text { b) Enhancing participatory fire } \\
\text { management. }\end{array}$ \\
\hline & & & & $\begin{array}{l}\text { c) Enhancing forest governance and } \\
\text { protection of forest resources. }\end{array}$ \\
\hline & & & & $\begin{array}{l}\text { d) Enhancing Sustainable forest } \\
\text { management. }\end{array}$ \\
\hline Uruguay & Basic & $\begin{array}{l}\text { Coastal and } \\
\text { marine } \\
\text { habitats }\end{array}$ & Current & $\begin{array}{l}\text { Restoration and maintenance of coastal } \\
\text { ecosystems services that provide } \\
\text { protection against extreme events and of } \\
\text { ecosystems services that protect drinking } \\
\text { water sources. }\end{array}$ \\
\hline Vanuatu & Basic & General & Planned & $\begin{array}{l}\text { Adaptation action building on and } \\
\text { incorporating taboos, conservation areas } \\
\text { and locally managed areas and protects } \\
\text { vulnerable habitats and ecosystems and } \\
\text { carbon sinks will be prioritized }\end{array}$ \\
\hline
\end{tabular}




\begin{tabular}{|c|c|c|c|c|}
\hline Venezuela & Robust & $\begin{array}{l}\text { Terrestrial } \\
\text { forests or } \\
\text { woodlands }\end{array}$ & Current & $\begin{array}{l}\text { Promotes sustainable forest management } \\
\text { projects, as environmental, social and } \\
\text { economic, under the principle of multiple } \\
\text { uses, promoting direct participation of } \\
\text { local communities and other social } \\
\text { organizations in the production, } \\
\text { processing and distribution of goods and } \\
\text { services derived from the forest }\end{array}$ \\
\hline Venezuela & Robust & $\begin{array}{l}\text { Terrestrial } \\
\text { forests or } \\
\text { woodlands }\end{array}$ & Current & $\begin{array}{l}\text { The Tree Mission is an ambitious national } \\
\text { reforestation plan It is driven by the state } \\
\text { since } 2006 \text { where participating } \\
\text { communities (Community Councils, } \\
\text { Committees Conservationists, Schools, } \\
\text { etc.) and public institutions. Reforestation } \\
\text { is made for purposes of education, } \\
\text { conservation, agro-based and industrial } \\
\text { integrated and sustainable management } \\
\text { oriented Good Living. contemplate the } \\
\text { collection of seeds and plants in nurseries } \\
\text { institutional, school or community, } \\
\text { planting and maintenance for four } \\
\text { consecutive years. To date they have } \\
\text { established more than } 30 \text { million plants }\end{array}$ \\
\hline \multirow{4}{*}{ Zambia } & \multirow{4}{*}{ Robust } & \multirow{4}{*}{$\begin{array}{l}\text { Agroforestry, } \\
\text { Grasslands } \\
\text { and } \\
\text { rangelands }\end{array}$} & \multirow{4}{*}{ Planned } & $\begin{array}{l}\text { Priority Actions: } 1 \text {. Guaranteed food } \\
\text { security through diversification and } \\
\text { promotion of Climate Smart Agricultural } \\
\text { (CSA) practices for crop, livestock and } \\
\text { fisheries production including } \\
\text { conservation of germplasm for land races } \\
\text { and their wild relatives }\end{array}$ \\
\hline & & & & $\begin{array}{l}\text { 1.1 Promote CSA practices through } \\
\text { conservation agriculture, agroforestry, use } \\
\text { of drought tolerant varieties, water use } \\
\text { efficiency management and fertilizer use } \\
\text { efficiency management }\end{array}$ \\
\hline & & & & Co-benefits: Poverty reduction \\
\hline & & & & $\begin{array}{l}\text { 1.3 Promote livestock CSA practices } \\
\text { through: improved feed management, } \\
\text { improved animal health, improved }\end{array}$ \\
\hline
\end{tabular}




\begin{tabular}{|c|c|c|c|c|}
\hline & & & & $\begin{array}{l}\text { rangeland management and use of } \\
\text { drought-tolerant breeds }\end{array}$ \\
\hline & & & & $\begin{array}{l}\text { Co-benefits:- Increased rural household } \\
\text { incomes from diversified production } \\
\text { systems }\end{array}$ \\
\hline \multirow{5}{*}{ Zambia } & \multirow{5}{*}{ Robust } & \multirow{5}{*}{ General } & \multirow{5}{*}{ Planned } & $\begin{array}{l}\text { 2. Develop a National Wildlife Adaptation } \\
\text { Strategy and ensure its implementation } \\
\text { through supportive policies, local } \\
\text { community, civil society and private sector } \\
\text { participation }\end{array}$ \\
\hline & & & & $\begin{array}{l}\text { 2.1 Develop a National Wildlife } \\
\text { Adaptation Strategy. }\end{array}$ \\
\hline & & & & $\begin{array}{l}2.2 \text { Map and protect wildlife corridors and } \\
\text { refuges }\end{array}$ \\
\hline & & & & $\begin{array}{l}\text { 2.3 Promote community / public / private } \\
\text { partnerships in the sustainable } \\
\text { management of wildlife resources }\end{array}$ \\
\hline & & & & $\begin{array}{l}\text { 2.4 Enforce equitable benefit sharing } \\
\text { arrangements among government, } \\
\text { communities and the private sector in the } \\
\text { management of wildlife resources }\end{array}$ \\
\hline Zambia & Basic & $\begin{array}{l}\text { Terrestrial } \\
\text { forests or } \\
\text { woodlands }\end{array}$ & Planned & $\begin{array}{l}\text { 7. Capacity building in Climate Smart } \\
\text { Agriculture (CSA), Sustainable Forest } \\
\text { Management (SFM), ... and climate change } \\
\text { planning }\end{array}$ \\
\hline
\end{tabular}




\begin{tabular}{|c|c|c|c|c|}
\hline & & & & $\begin{array}{l}\text { 8. Conduct trainings for farmers, extension } \\
\text { and technical staff on CSA, SFM, SFA, } \\
\text { RET, EWS and climate change planning }\end{array}$ \\
\hline & & & & $\begin{array}{l}\text { 9. Conduct public awareness campaigns } \\
\text { on climate change, CSA, SFM, SFA, RET } \\
\text { and EWS }\end{array}$ \\
\hline \multirow{4}{*}{ Zambia } & \multirow{4}{*}{ Basic } & \multirow{4}{*}{$\begin{array}{l}\text { River } \\
\text { catchments, } \\
\text { Terrestrial } \\
\text { forests or } \\
\text { woodlands }\end{array}$} & \multirow{4}{*}{ Planned } & $\begin{array}{l}\text { 3. Protection and conservation of water } \\
\text { catchment areas and enhanced investment } \\
\text { in water capture, storage and transfer } \\
\text { (linked to agriculture, energy, ecological, } \\
\text { industrial and domestic use purposes) in } \\
\text { selected watersheds }\end{array}$ \\
\hline & & & & $\begin{array}{l}\text { 3.1 Promote the protection of catchment } \\
\text { forests in the Zambezi, Kafue and } \\
\text { Luangwa watersheds }\end{array}$ \\
\hline & & & & 3.7 Undertake restoration projects \\
\hline & & & & $\begin{array}{l}\text { Co-Benefits: Improved water security for } \\
\text { ecological, domestic and industrial } \\
\text { purposes, Increased hydrological systems } \\
\text { resilience and reduced vulnerability to } \\
\text { climate change impacts }\end{array}$ \\
\hline & & & & \\
\hline
\end{tabular}




\begin{tabular}{|l|l|l|l|l|}
\hline Zimbabwe & Basic & Agroforestry & Planned & $\begin{array}{l}\text { Promoting non-timber forest products and } \\
\text { sustainable agro-forestry practices to } \\
\text { enhance forest-based adaptation. }\end{array}$ \\
\hline
\end{tabular}

